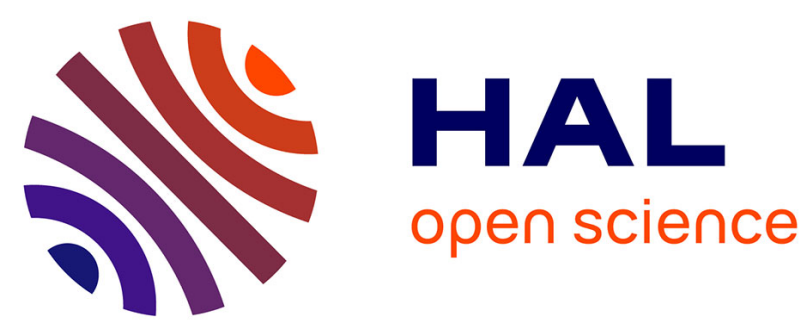

\title{
Probing the low-temperature chemistry of di-n-butyl ether: Detection of previously unobserved intermediates
}

Luc-Sy Tran, Julia Wullenkord, Yuyang Li, Olivier Herbinet, Meirong Zeng, Fei Qi, Katharina Kohse-Höinghaus, Frédérique Battin-Leclerc

\section{- To cite this version:}

Luc-Sy Tran, Julia Wullenkord, Yuyang Li, Olivier Herbinet, Meirong Zeng, et al.. Probing the low-temperature chemistry of di-n-butyl ether: Detection of previously unobserved intermediates. Combustion and Flame, 2019, 210, pp.9-24. 10.1016/j.combustflame.2019.08.022 . hal-02277940

\author{
HAL Id: hal-02277940 \\ https://hal.science/hal-02277940
}

Submitted on 4 Sep 2019

HAL is a multi-disciplinary open access archive for the deposit and dissemination of scientific research documents, whether they are published or not. The documents may come from teaching and research institutions in France or abroad, or from public or private research centers.
L'archive ouverte pluridisciplinaire HAL, est destinée au dépôt et à la diffusion de documents scientifiques de niveau recherche, publiés ou non, émanant des établissements d'enseignement et de recherche français ou étrangers, des laboratoires publics ou privés. 


\title{
Probing the low-temperature chemistry of di-n-butyl ether: Detection of previously unobserved intermediates
}

\author{
Luc-Sy Tran',2,3,*, Julia Wullenkord33, Yuyang Li, , Olivier Herbinet², Meirong Zeng4, Fei \\ Qi $^{4}$, Katharina Kohse-Höinghaus ${ }^{3}$, Frédérique Battin-Leclerc ${ }^{2}$
}

${ }^{1}$ Physicochimie des Processus de Combustion et de l'Atmosphère (PC2A), CNRS, Université de Lille, F59000 Lille, France

2 Laboratoire Réactions et Génie des Procédés (LRGP), CNRS, Université de Lorraine, ENSIC, 1, rue Grandville, BP 20451, 54001 Nancy Cedex, France

3 Department of Chemistry, Bielefeld University, Universitätsstraße 25, D-33615 Bielefeld, Germany

${ }^{4}$ School of Mechanical Engineering, Shanghai Jiao Tong University (SJTU), Shanghai 200240, PR China

* Corresponding author: Dr. Luc-Sy Tran

Physicochimie des Processus de Combustion et de l'Atmosphère (PC2A),

CNRS, Université de Lille, F-59000 Lille, France

E-mail: luc-sy.tran@univ-lille.fr 


\section{Abstract}

Di- $n$-butyl ether (DBE, $\mathrm{C}_{8} \mathrm{H}_{18} \mathrm{O}$ ) has been proposed as a promising biofuel for diesel engines, but details of its low-temperature (LT) oxidation chemistry are not well understood. This paper reports new speciation data obtained in the temperature range of 400-1100 $\mathrm{K}$ at $\phi=1$ and nearly-atmospheric pressure, using a plug flow reactor (PFR) combined with electron ionization (EI) molecular-beam mass spectrometry (MBMS) and two different jet-stirred reactors (JSRs) coupled with either online gas chromatography (GC) or tunable synchrotron vacuum ultraviolet (SVUV) photoionization (PI)-MBMS.

The experimental results confirm that DBE is very reactive and exhibits two negativetemperature coefficient (NTC) zones around 500-550 K and 650-750 K. Speciation data with about $40 \mathrm{C}_{0}-\mathrm{C}_{8}$ species are presented, including about 20 LT species not reported previously. Among those, fuel-specific $\mathrm{C}_{8} \mathrm{H}_{16} \mathrm{O}_{2}$ cyclic ethers were quantified. Also, butanoic acid, which is present in highest amounts among the detected LT intermediates, and $\mathrm{C}_{8} \mathrm{H}_{14} \mathrm{O}_{3}$ diones, were found to peak already near $500 \mathrm{~K}$, suggesting their importance in the LT chemistry of DBE. Signals of several highly oxygenated peroxides (e.g., $\mathrm{C}_{8} \mathrm{H}_{14} \mathrm{O}_{5}$ and $\mathrm{C}_{8} \mathrm{H}_{16} \mathrm{O}_{6}$ ) were detected, indicating third $\mathrm{O}_{2}$ addition steps. Respective reaction pathways are suggested and discussed based on these experimental results.

To better understand the LT chemistry of DBE, the present data were compared to two recent DBE models [L. Cai et al. Combust. Flame. 161 (2014) 798-809 and S. Thion et al. Combust. Flame 185 (2017) 4-15]. Significant discrepancies between the experimental data and both models were found for important LT intermediates, of which many were not included in the respective mechanisms. The results reported in the present study thus provide new opportunities for refining DBE kinetic models.

Keywords: Biofuel, di-n-butyl ether, low-temperature oxidation, butanoic acid, third $\mathrm{O}_{2}$ addition, double-NTC behavior. 


\section{Introduction}

With attractive properties for compression-ignition engines, such as a high cetane number ( 100) and high energy density ( $\sim 38 \mathrm{MJ} / \mathrm{kg})$, di- $n$-butyl ether $\left(\mathrm{DBE}, \mathrm{C}_{8} \mathrm{H}_{18} \mathrm{O}\right)$ has been considered as a promising biofuel [1-8]. The use of DBE as a fuel additive has been shown to decrease soot emissions from diesel engines $[2,3,5]$. While DBE has been extensively examined under engine conditions $[2-5,9,10]$, the fundamental oxidation chemistry of this fuel is not similarly well investigated. Recent studies address the high temperature (HT) oxidation of DBE, including the measurements of ignition delay times in a shock tube [11], premixed laminar flame speeds [12], and gaseous species [13] or soot particles [14] in flames. The low-temperature (LT) oxidation of DBE was addressed in a study of Cai et al. [12] who determined ignition delay times of DBE/air mixtures in the range of $485-525 \mathrm{~K}$ at atmospheric pressure. These authors developed the first kinetic model for the LT oxidation of this fuel using rate parameters of the primary reaction subset that were mainly determined by rate rules or by analogy to structurally similar species. Recently, Thion et al. [15] investigated the oxidation of DBE in a jet-stirred reactor (JSR) in the 470-1250 K temperature range and at 1 and $10 \mathrm{~atm}$. Reactants, main species, and about $18 \mathrm{C}_{1}-\mathrm{C}_{5}$ intermediate species were quantified using gas chromatography. These authors developed a new kinetic model with a sub-mechanism of DBE based on the previous work of Cai et al. [12], to which modifications were made using rate coefficients from analogies with butanol and theoretical calculations.

In the present study, we have examined in unprecedented detail, using different reactors and detection methods, the fuel-specific intermediate species produced in the LT oxidation of DBE. The experimental results have been compared to the two literature models $[12,15]$ and can be used to enhance the understanding of this fuel's LT chemistry.

\section{Experimental methods and modeling procedures}

Two JSR setups and a plug flow reactor (PFR) were used in the present study. Oxidation products from the JSRs were analyzed either by online gas chromatography (GC) or by tunable synchrotron vacuum ultraviolet (SVUV) photoionization (PI) molecular-beam mass spectrometry (MBMS), while those from the PFR were measured using electron ionization (EI)MBMS. The combination of different reactor types and analytical methods provides 
complementary information that facilitates identification and quantification of key intermediates. Experimental conditions are summarized in Table 1.

Table 1. Experimental conditions.

\begin{tabular}{|c|c|c|c|c|c|c|c|c|c|}
\hline \multirow{2}{*}{\multicolumn{2}{|c|}{ Reactor }} & \multirow[b]{2}{*}{$\phi$} & \multirow{2}{*}{$\begin{array}{l}\tau \\
(\mathbf{s})\end{array}$} & \multirow[b]{2}{*}{ p (kPa) } & \multirow[b]{2}{*}{$\mathbf{T}(\mathbf{K})$} & \multicolumn{3}{|c|}{ Initial mole fraction } & \multirow{2}{*}{$\begin{array}{l}\text { Diagnostic } \\
\text { technique }\end{array}$} \\
\hline & & & & & & $\mathrm{He} / \mathrm{Ar}$ & & & \\
\hline \multirow[t]{2}{*}{ JSR } & Nancy & 1 & 2 & 106.7 & $435-1100$ & 0.870 & 0.120 & 0.010 & $\begin{array}{l}\text { GC-TCD-FID/ } \\
\text { methanizer-MS }\end{array}$ \\
\hline & Hefei & 1 & 2 & 106.7 & $440-750$ & 0.870 & 0.120 & 0.010 & SVUV-PI-MBMS \\
\hline \multirow[t]{3}{*}{ PFR } & Bielefeld & 1 & $2 \mathbf{b}$ & 97 & $448-1015$ & 0.935 & 0.060 & 0.005 & EI-MBMS \\
\hline & Bielefeld c & 1 & $1^{\mathbf{b}}$ & 97 & $448-900$ & 0.935 & 0.060 & 0.005 & EI-MBMS \\
\hline & Bielefeld c & 0.7 & $2^{\mathbf{b}}$ & 97 & $448-900$ & 0.909 & 0.086 & 0.005 & EI-MBMS \\
\hline
\end{tabular}

a He: GC experiments, Ar: MBMS experiments.

${ }^{b}$ At $\sim 1000 \mathrm{~K}$ (in the PFR experiments, the gas flow was fixed, i.e. residence time varies with reactor temperature).

c Only the fuel consumption profiles were measured in these supplemental experiments.

\subsection{Combination of JSR and GC (Nancy)}

Details of the JSR-GC system were previously described in $[16,17]$, therefore only main features of the experimental apparatus are summarized below. The JSR $\left(81.2 \mathrm{~cm}^{3}\right.$ volume $)$ is made of fused silica and heated electrically. The JSR outlet is directly connected to three GC instruments, allowing online analyses of oxidation products. The GC systems were equipped with different columns (Carbosphere, PlotQ, and HP-5 columns) and detectors, i.e. a thermal conductivity detector (TCD), a flame ionization detector (FID) coupled to a methanizer for quantification, and a mass spectrometric detector (MS) with electron ionization at $70 \mathrm{eV}$ for identification. The temperature of the transfer lines and of the GC-loop/injectors was kept at $435 \mathrm{~K}$, lower than the usual value of $523 \mathrm{~K}$, to avoid DBE pre-reactions. Calibrations were performed using cold-gas mixtures whenever available. For other species, calibration factors were determined relying on hydrogenation by the methanizer, based on alkanes with the same number of carbon atoms, with an uncertainty $<15 \%$.

Experiments were performed for a mixture of $\mathrm{DBE} / \mathrm{O}_{2} / \mathrm{He}(0.01 / 0.12 / 0.87)$ with an equivalence ratio $\phi=1$, a residence time of $2 \mathrm{~s}$, a temperature range of 435-1100 $\mathrm{K}$, and a pressure of $106.7 \mathrm{kPa}$. Flow rates of liquid DBE (Sigma-Aldrich, purity $\geq 99.3 \%$ ) were controlled 
using a Coriolis flow controller followed by an evaporator set to $435 \mathrm{~K}$. The flow rates of helium (Messer, 99.99\%) and oxygen (Messer, 99.999\%) were controlled by Bronkhorst mass flow controllers.

\subsection{Combination of JSR and SVUV-PI-MBMS (Hefei)}

A second JSR of $100 \mathrm{~cm}^{3}$ volume coupled to SVUV-PI-MBMS was used with three objectives: (i) to confirm important trends obtained in the JSR-GC experiments, (ii) to detect species that cannot be measured by GC such as hydroperoxide species, and (iii) to assist in the identification of important LT intermediates. A detailed description of the apparatus is available in $[18,19]$. Gas samples were extracted from the JSR by a quartz sampling cone of $70 \mu \mathrm{m}$ orifice, forming a molecular beam that was then intersected and ionized by the tunable synchrotron VUV light. The ions were transferred by an ion guide to a home-made reflectron time-of-flight mass spectrometer (TOF-MS) with a mass-resolving power of $m / \Delta m \sim 2500$. The temperature scan (440-750 K) was performed at photon energies of 16.64, 11.0, 10.5, 10.0, 9.50, and 9.0 eV. For species identification, the photoionization efficiency (PIE) spectra were measured in a photon energy range of 8-11.5 eV, with uncertainties in the determination of ionization energies of \pm 0.05 and $\pm 0.10 \mathrm{eV}$ for strong and poor signal-to-noise ratio, respectively. Mole fractions were evaluated as previously reported [20].

The same operating conditions as used in the JSR-GC experiment were applied, but replacing He by Ar that served as a reference in the SVUV-PI-MBMS data evaluation. Flow rates of liquid DBE (Aladdin, purity $\geq 99.5 \%$ ) were controlled using a Coriolis flow controller followed by an evaporator set to $435 \mathrm{~K}$.

\subsection{Combination of PFR and EI-MBMS (Bielefeld)}

A detailed description of the PFR-EI-MBMS setup is given in [21-23]. The reactor consists of a fused silica tube of $1.40 \mathrm{~m}$ length and $8 \mathrm{~mm}$ inner diameter. Eight individual heating zones along a length of $1.30 \mathrm{~m}$, regulated via $8 \mathrm{Ni}-\mathrm{Cr} / \mathrm{Ni}$-thermocouples, allow for temperature control in the range up to $1100 \mathrm{~K}$. The overall temperature uncertainty is estimated to be $\pm 15 \mathrm{~K}$ [21].

Gas samples were extracted at the reactor exit via a quartz probe ( $\sim 50 \mu$ orifice diameter $)$ and expanded to $10^{-4}$ mbar. Skimmed through a copper cone, the central part of the formed molecular beam was then directed into the ion source of the mass spectrometer at a pressure of 
$<10^{-6}$ mbar and crossed with an electron beam of $17 \mathrm{eV}$. Ions were accelerated into the reflectron TOF-MS $(m / \Delta m \sim 2200)$. The broad energy distribution of $1 \mathrm{eV}$ (FWHM) allows for the detection of all species in one scan, including argon which served as a reference. The quantification followed routines previously reported in [21] and mainly adopted from [24]. Briefly, calibration factors for major species $\left(\mathrm{O}_{2}\right.$, fuel, $\mathrm{H}_{2}, \mathrm{CO}, \mathrm{CO}_{2}$, and $\left.\mathrm{CO}\right)$ were determined from an internal calibration strategy based on the $\mathrm{C}, \mathrm{H}$, and $\mathrm{O}$ atom balance at non-reactive conditions and high-temperature equilibrium. Intermediate species were quantified using calibration factors determined either from energy-dependent cold-gas measurements of gas mixtures with defined mole fraction ("direct calibration") or by simulating the signal ("convolution" [24]). Uncertainties for major species are expected to be within 15\%, while those for intermediate species might vary within a factor of 2-4 depending on the calibration method and associated reference data.

A mixture of $\mathrm{DBE} / \mathrm{O}_{2} / \mathrm{Ar}(0.005 / 0.060 / 0.935)$ was investigated with an equivalence ratio of $\phi=1$, a total flow of $0.5 \mathrm{slm}$ and gas velocity of $0.28 \mathrm{~m} / \mathrm{s}$ (at $448 \mathrm{~K}$ and $97 \mathrm{kPa}$ ). The temperaturedependent residence time in the reactor was determined to be $\sim 2-4 \mathrm{~s}$. Liquid DBE was introduced with a dialysis pump (Protea PM-1000) and evaporated at $448 \mathrm{~K}$. To examine potential effects of stoichiometry and residence time on the two NTC zones (double-NTC behavior), supplemental measurements were performed with a fuel-lean mixture ( $\phi=0.7)$ and residence times of 1-2 s. Carbon balances were checked for all JSR and PFR experiments and are close to $100 \%$.

\subsection{Kinetic modeling}

The resulting experimental data were compared to two recent literature DBE models developed by Cai et al. [12] ("Cai model") and by Thion et al. [15] ("Thion model"), respectively. The reason for the comparisons is to show how the present experimental results could offer a more complete picture of DBE LT oxidation than reflected in present models. By explaining the additional information gained from the experiments versus the current mechanistic modeling, the need for more in-depth modeling of this system could be evidenced. Improving the model is beyond the scope of the present study, but some indications where further work may be necessary will be given in this paper. Simulations were performed using the OpenSMOKE++ package [25] with isothermal-constant pressure approach for the JSR, whereas a multi-zone non-isothermal solution was applied following $[21,26]$ for the PFR setup. 
Detailed descriptions of the two literature models are given in [12,15]. Briefly, the Cai model [12] includes 29 reaction classes of both low- and high-temperature kinetics of DBE. Rate coefficients were mainly determined using rate rules from Sarathy et al. [27], while thermodynamic data were calculated using the THERM program of Ritter and Bozzelli [28]. This model had been tested against data sets of ignition delay times (485-525 K, $\phi=0.5-1.0$ ) and flame speeds $(\phi=0.7-1.5)$ at atmospheric pressure. The Thion model [15] includes a $\mathrm{C}_{0}-\mathrm{C}_{4}$ core model developed by Fenard et al. [29] and a DBE sub-mechanism that was modified from the previous work of Cai et al. [12]. As explained in their paper, Thion et al. [15] have made several modifications for the DBE sub-mechanism using rate coefficients from analogies with butanol and computations. For example, rate coefficients of $\mathrm{H}$-abstractions at $\mathrm{C}_{\alpha}$ (neighboring the ether group) by $\mathrm{OH}$ were reduced by a factor of 1.5 from the Cai model, while those by $\mathrm{HO}_{2}$ radicals were taken from the calculation of Mendes et al. [30], which are lower than those used in the Cai model by a factor of around 80. Furthermore, rate coefficients for the decomposition of ketohydroperoxides used in the Thion model are much lower than in the Cai model by factors of 20-20,000 (depending on temperature). The Thion model had been tested against the JSR data from their own study as well as ignition delay times and laminar burning velocities from the literature.

\section{Results and discussion}

The complete JSR and PFR speciation datasets as well as some supportive information are provided in Supplemental Materials SM1 and SM2. Selected mole fraction profiles of main species and intermediates will be discussed in Sections 3.1 and 3.2, experiments and model predictions will be compared in Section 3.3, and newly-proposed reaction pathways for DBE LT oxidation will be presented in Section 3.4.

\subsection{Consumption of reactants and the formation of main products}

Figure 1 presents the mole fraction profiles of DBE and $\mathrm{O}_{2}$ as a function of temperature, (a) obtained in the JSR-GC and JSR-PI-MBMS experiments and (b) in the PFR-EI-MBMS experiments, (c) a comparisons between the two reactor types, and (d) a test for different equivalence ratio and residence time. 

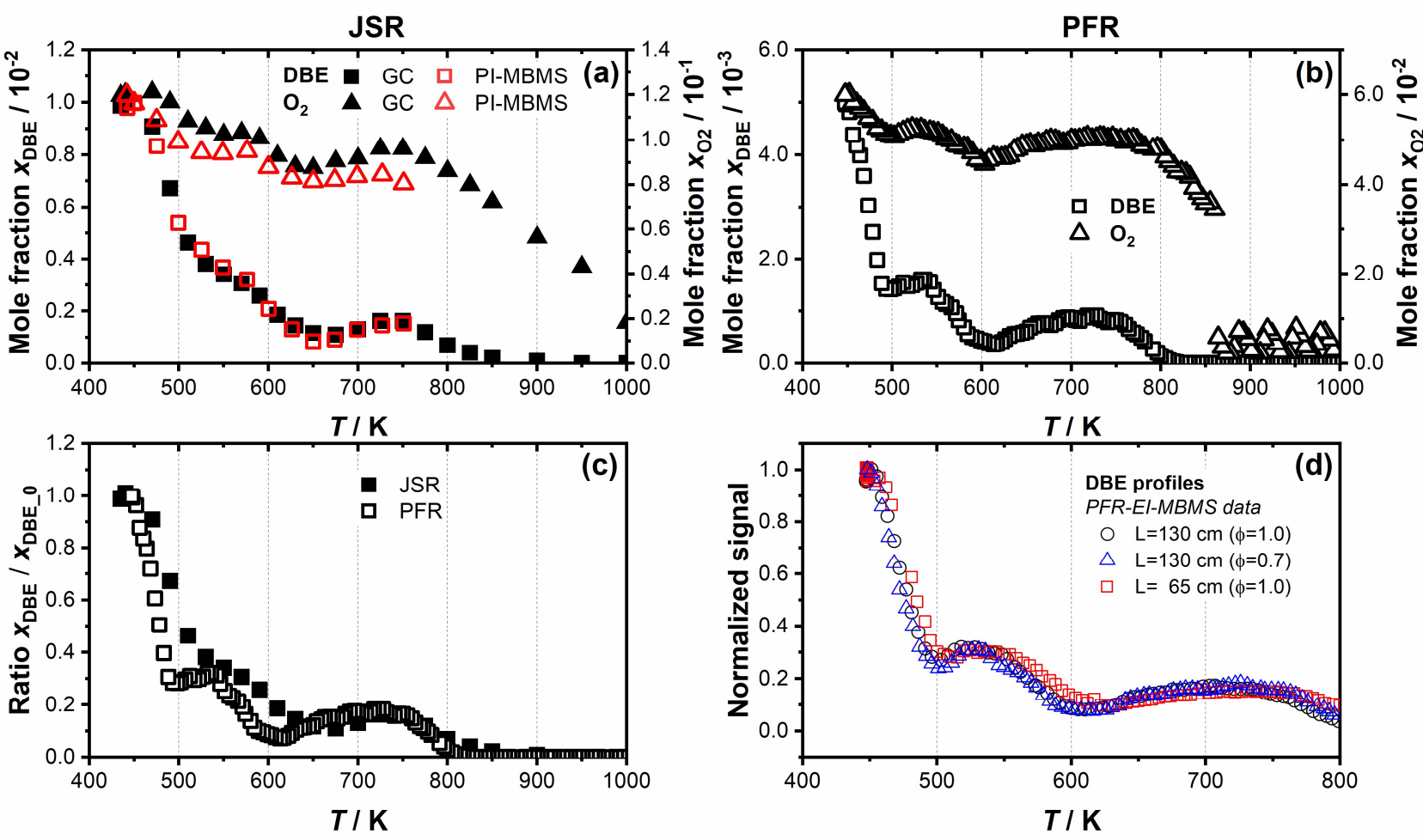

Figure 1. Experimental mole fraction profiles of DBE and $O_{2}$. (a) JSR ( $\phi=1.0,1 \%$ DBE), (b) PFR ( $\phi=1.0$, 0.5\% DBE), (c) DBE profile in JSR-GC and PFR-EI-MBMS experiments, (d) DBE profiles for different $\phi$ and PFR lengths L. Profiles in (c) and (d) are normalized by the respective inlet DBE mole fractions.

Very good agreement of the JSR data obtained by GC and by PI-MBMS is seen (Figure 1a), ensuring similar chemical behavior in both JSRs. Agreement was also observed for intermediate species as exemplarily shown in Figure S1 in SM2. DBE is very reactive with consumption starting near $450 \mathrm{~K}$; about $90 \%$ of DBE is already consumed at the temperature of the highest LT reactivity (JSR: 650 K, PFR: 615 K). Particularly, DBE consistently exhibits two NTC zones as was previously observed in the JSR study of Thion et al. [15]. This double-NTC behavior is also evident in the $\mathrm{O}_{2}$ profile (Figure 1a,b) and in those of the main products (see below). Because of a more pronounced double-NTC behavior between 475-615 K in the PFR (Figure 1c), effects of equivalence ratio and residence time were inspected in the PFR, reducing the residence time by heating only half of the reactor length. Figure $1 \mathrm{~d}$ shows that the double-NTC behavior occurs consistently under all investigated conditions.

The DBE profile is composed of five zones. In the first zone (JSR: 450-525 K, PFR: 450-500 K), DBE is quickly consumed. In the second zone, which we will call the first NTC zone (JSR: 525$575 \mathrm{~K}$, PFR: $500-545 \mathrm{~K}$ ), the reactivity of the fuel is reduced while it increases again in the third zone (JSR: 575-650 K, PFR: 545-615 K). The fourth zone (JSR: 650-750 K, PFR: 615-750 K), here called the second NTC zone, features a further decrease in fuel reactivity. This second NTC zone 
is rather weak, indicating that DBE exhibits a strong LT chemistry, in agreement with observations in [15]. In the fifth zone (above $750 \mathrm{~K}$ ), the reactivity rises again, and DBE is totally consumed above $900 \mathrm{~K}$.

Figure 2 presents the mole fraction profiles of $\mathrm{CO}$ and $\mathrm{CO}_{2}$; quantitative $\mathrm{H}_{2}$ and $\mathrm{H}_{2} \mathrm{O}$ profiles are included in SM2. These profiles again evidence the double-NTC behavior. Interestingly, in the LT range $(<750 \mathrm{~K})$, the peak mole fractions of $\mathrm{CO}$ and $\mathrm{CO}_{2}$ appear at similar temperatures (see also inset in Figure 2). The $\mathrm{CO}_{2}$ peak is even observed at slightly lower temperatures, indicating that $\mathrm{CO}_{2}$ is not predominantly formed from $\mathrm{CO}$, but can be directly produced through LT reactions of the fuel. In a higher temperature region $(>750 \mathrm{~K})$, the $\mathrm{CO}_{2}$ mole fraction increases with the temperature and exhibits a profile shape of a final oxidation product, while CO shows a profile shape of an oxidation intermediate and reaches its maximum at approximately $950 \mathrm{~K}$ (JSR) or $850 \mathrm{~K}$ (PFR). The $\mathrm{CO}_{2}$ profile in the PFR reaches a plateau at $870 \mathrm{~K}$, while that in the JSR still increases from this temperature on, indicating that the equilibrium is achieved faster in the PFR experiments.
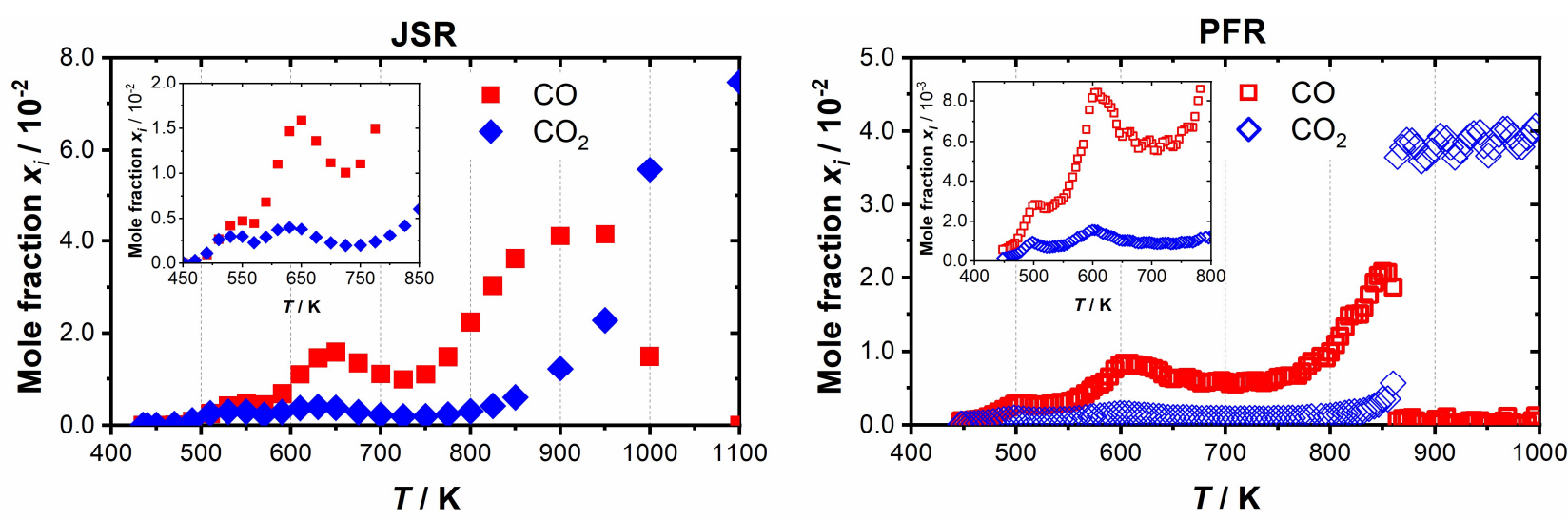

Figure 2. Experimental mole fraction profiles of $\mathrm{CO}$ and $\mathrm{CO}_{2}$. Left: JSR with GC, right: PFR. The inset enlarges the region of LT oxidation.

\subsection{Formation of intermediate species}

An overview of the detected intermediates will be presented in Section 3.2.1, followed by a discussion of the double-NTC reaction mechanism in Section 3.2.2. Newly-identified fuelspecific stable and reactive intermediates will be presented in Sections 3.2.3 and 3.2.4, respectively. 


\subsubsection{Overview of the detected intermediates}

Peak mole fractions of intermediates measured in the oxidation of DBE are given in Table 2, together with the temperatures at which their respective maximum mole fraction occurs. About 40 intermediate species including isomers were detected, with about half of them not reported previously [15] and about ten of them not included in previous models [12,15]. In the following, we will use the nomenclature from the Thion et al. [15] model. It should be noted that Table 2 includes some information on the detection and quantification method, and it provides some indications of experimental difficulties that make unambiguous assignment or quantification problematic. Generally, the quantitative values in Table 2 for the JSR experiments relied predominantly on GC (b) if not indicated otherwise, where PI-MBMS (d) was used. For the PFR values reported in Table 2, the quantification relied on the evaluation of the EI-MBMS signal assuming the cross section of the dominant isomer ( $\mathbf{c}$ ) identified in the JSR experiments by GC or PI-MBMS. Difficulties were encountered when neither PI nor EI cross sections were available (g) and only intensity values can thus be given for these species. Similarly, some species could only be detected in the JSR experiments because of the limited mass range for the EI-MBMS experiments (i). Also, in some cases, multiple isomers may contribute, and thus only a tentative assignment to a plausible structure is reported as an example in these cases (i).

Table 2. Intermediate species detected experimentally in DBE oxidation. $\mathbf{M}$ : nominal mass. $\mathbf{x}_{\text {max }}$ : peak mole fraction. $\mathbf{T}$ : temperature at $\mathrm{x}_{\max }$. Bold font highlights intermediates with peak mole fraction found at relatively low temperature. ${ }^{\text {a }}$ ND: not detected previously in $[12,15]$; NM: not included in the literature models of $[12,15] .^{\mathbf{b}}$ From GC if not noted differently. ${ }^{\mathbf{c}}$ Evaluated using the cross section of the most abundant isomer. ${ }^{\mathbf{d}}$ From PI-MBMS. $\mathbf{e}$ Two equivalent peaks. ${ }^{\mathbf{f}}$ Plateau. $\mathbf{g}$ Signal intensities (quantification not possible because of lacking PI/EI cross sections). ${ }^{\mathbf{i}}$ Beyond the highest mass limit set for the used mass spectrometer. $\mathbf{j}$ Tentative assignment of structures and several possible isomers; structure provided in the next column is just an example. ${ }^{\mathbf{k}}$ Nomenclature explained in SM2 Figure S2 and corresponding text.

\begin{tabular}{|c|c|c|c|c|c|c|c|c|c|}
\hline \multirow{2}{*}{ M } & \multicolumn{4}{|l|}{ Species } & \multirow{2}{*}{ Note ${ }^{a}$} & \multicolumn{2}{|l|}{$J_{S R} \mathbf{b}$} & \multicolumn{2}{|l|}{$\mathrm{PFR}^{\mathrm{c}}$} \\
\hline & Formula & Name & & Structure & & $\mathrm{T}(\mathrm{K})$ & $\mathrm{X}_{\max }$ & $\mathrm{T}(\mathrm{K})$ & $\mathrm{X}_{\max }$ \\
\hline 16 & $\mathrm{CH}_{4}$ & $\mathrm{CH}_{4}$ & Methane & & & 850 & $2.63 \mathrm{E}-03$ & 846 & $1.02 \mathrm{E}-03$ \\
\hline 28 & $\mathrm{C}_{2} \mathrm{H}_{4}$ & $\mathrm{C}_{2} \mathrm{H}_{4}$ & Ethylene & $\overline{\overline{ }}$ & & 850 & $7.36 \mathrm{E}-03$ & 818 & $4.16 \mathrm{E}-03$ \\
\hline \multirow[t]{2}{*}{30} & $\mathrm{C}_{2} \mathrm{H}_{6}$ & $\mathrm{C}_{2} \mathrm{H}_{6}$ & Ethane & $\gamma$ & & 850 & $1.15 \mathrm{E}-04$ & 603 & $2.47 \mathrm{E}-04$ \\
\hline & $\mathrm{CH}_{2} \mathrm{O}$ & $\mathrm{CH}_{2} \mathrm{O}$ & Formaldehyde & $=0$ & & 675 & $4.05 \mathrm{E}-03$ & 603 & $2.60 \mathrm{E}-03$ \\
\hline 42 & $\mathrm{C}_{3} \mathrm{H}_{6}$ & $\mathrm{C}_{3} \mathrm{H}_{6}$ & Propene & 7 & & 775 & $2.56 \mathrm{E}-03$ & 782 & 8.34E-04 \\
\hline
\end{tabular}


Table 2 (continued)

\begin{tabular}{|c|c|c|c|c|c|c|c|c|c|}
\hline \multirow[t]{3}{*}{44} & $\mathrm{C}_{3} \mathrm{H}_{8}$ & $\mathrm{C}_{3} \mathrm{H}_{8}$ & Propane & 1 & & 570 & $1.75 \mathrm{E}-04$ & - & - \\
\hline & \multirow[t]{2}{*}{$\mathrm{C}_{2} \mathrm{H}_{4} \mathrm{O}$} & $\mathrm{CH}_{3} \mathrm{CHO}$ & Acetaldehyde & & & $650^{d}$ & $1.02 \mathrm{E}-03$ & & $1.72 \mathrm{E}-03$ \\
\hline & & $\mathrm{C}_{2} \mathrm{H}_{4} \mathrm{O} 1,2$ & Ethylene oxide & & & $\begin{array}{l}610 / \\
825^{e}\end{array}$ & $\begin{array}{l}1.12 \mathrm{E}- \\
04 / \\
1.96 \mathrm{E}-04\end{array}$ & 663 & \\
\hline \multirow[t]{2}{*}{46} & $\mathrm{C}_{2} \mathrm{H}_{6} \mathrm{O}$ & $\mathrm{C}_{2} \mathrm{H}_{5} \mathrm{OH}$ & Ethanol & $\mathrm{OH}$ & & 610 & $1.27 \mathrm{E}-04$ & - & - \\
\hline & $\mathrm{CH}_{2} \mathrm{O}_{2}$ & $\mathrm{HCOOH}$ & Formic acid & $\mathrm{O}=\mathrm{OH}$ & & $576^{d}$ & $4.62 \mathrm{E}-04$ & 571 & $2.94 \mathrm{E}-04$ \\
\hline 48 & $\mathrm{CH}_{4} \mathrm{O}_{2}$ & $\mathrm{CH}_{3} \mathrm{O}_{2} \mathrm{H}$ & Methyl peroxide & & ND & $626^{d}$ & $1.95 \mathrm{E}-04$ & 594 & f \\
\hline 54 & $\mathrm{C}_{4} \mathrm{H}_{6}$ & $1,3-\mathrm{C}_{4} \mathrm{H}_{6}$ & 1,3-Butadiene & & & 800 & $5.03 \mathrm{E}-05$ & 782 & $6.05 \mathrm{E}-05$ \\
\hline \multirow[t]{3}{*}{56} & \multirow[t]{2}{*}{$\mathrm{C}_{4} \mathrm{H}_{8}$} & 1- $\mathrm{C}_{4} \mathrm{H}_{8}$ & 1-Butene & & & 775 & 7.56E-04 & \multirow{2}{*}{782} & \multirow[t]{2}{*}{$2.55 \mathrm{E}-04$} \\
\hline & & $2-\mathrm{C}_{4} \mathrm{H}_{8}$ & 2-Butene & & & 775 & $1.90 \mathrm{E}-05$ & & \\
\hline & $\mathrm{C}_{3} \mathrm{H}_{4} \mathrm{O}$ & $\mathrm{C}_{2} \mathrm{H}_{3} \mathrm{CHO}$ & Acrolein & & & 800 & $1.66 \mathrm{E}-04$ & 814 & $5.70 \mathrm{E}-05$ \\
\hline \multirow[t]{4}{*}{58} & $\mathrm{C}_{4} \mathrm{H}_{10}$ & $\mathrm{nC}_{4} \mathrm{H}_{10}$ & $n$-Butane & & & 750 & $3.58 \mathrm{E}-05$ & - & - \\
\hline & \multirow[t]{3}{*}{$\mathrm{C}_{3} \mathrm{H}_{6} \mathrm{O}$} & $\mathrm{C}_{3} \mathrm{H}_{6} \mathrm{O} 1,2$ & Propylene oxide & & & $\begin{array}{l}675 / \\
775^{e}\end{array}$ & $\begin{array}{l}3.24 \mathrm{E}- \\
04 / \\
2.87 \mathrm{E}-04\end{array}$ & \multirow{3}{*}{507} & \multirow[t]{3}{*}{$4.09 \mathrm{E}-04$} \\
\hline & & $\mathrm{CH}_{3} \mathrm{COCH}_{3}$ & Acetone & & & 550 & $4.58 \mathrm{E}-04$ & & \\
\hline & & $\mathrm{C}_{2} \mathrm{H}_{5} \mathrm{CHO}$ & Propanal & & & 550 & $1.13 \mathrm{E}-03$ & & \\
\hline \multirow[t]{2}{*}{60} & $\mathrm{C}_{3} \mathrm{H}_{8} \mathrm{O}$ & $\mathrm{C}_{3} \mathrm{H}_{7} \mathrm{OH}$ & Propanol & & ND, NM & 590 & $6.30 \mathrm{E}-05$ & - & - \\
\hline & $\mathrm{C}_{2} \mathrm{H}_{4} \mathrm{O}_{2}$ & $\mathrm{CH}_{3} \mathrm{COOH}$ & Acetic acid & & ND & 550 & $1.32 \mathrm{E}-03$ & 498 & $1.17 \mathrm{E}-03$ \\
\hline 70 & $\mathrm{C}_{4} \mathrm{H}_{6} \mathrm{O}$ & $\mathrm{sC}_{3} \mathrm{H}_{5} \mathrm{CHO}$ & 2-Butenal & & ND & 700 & $7.05 \mathrm{E}-05$ & 691 & $6.54 \mathrm{E}-05$ \\
\hline 72 & $\mathrm{C}_{4} \mathrm{H}_{8} \mathrm{O}$ & $\mathrm{nC}_{3} \mathrm{H}_{7} \mathrm{CHO}$ & n-Butanal & & & $\begin{array}{l}590 / \\
725^{e}\end{array}$ & \begin{tabular}{|l|}
$2.53 \mathrm{E}-03 /$ \\
$2.93 \mathrm{E}-03$
\end{tabular} & $\begin{array}{l}571 / \\
723 \mathrm{e}\end{array}$ & $\begin{array}{l}1.74 \mathrm{E}-03 / \\
1.95 \mathrm{E}-03\end{array}$ \\
\hline \multirow[t]{2}{*}{74} & $\mathrm{C}_{4} \mathrm{H}_{10} \mathrm{O}$ & $\mathrm{pC}_{4} \mathrm{H}_{9} \mathrm{OH}$ & n-Butanol & & & $\begin{array}{l}610- \\
735^{f}\end{array}$ & $1.02 \mathrm{E}-04$ & - & - \\
\hline & $\mathrm{C}_{3} \mathrm{H}_{6} \mathrm{O}_{2}$ & $\mathrm{C}_{2} \mathrm{H}_{5} \mathrm{COOH}$ & Propanoic acid & & ND, NM & 550 & $3.43 \mathrm{E}-04$ & 498 & $3.80 \mathrm{E}-04$ \\
\hline 76 & $\mathrm{C}_{3} \mathrm{H}_{8} \mathrm{O}_{2}$ & $\mathrm{nC}_{3} \mathrm{H}_{7} \mathrm{O}_{2} \mathrm{H}$ & Propylhydroperoxide & & ND & $576^{d}$ & $2.78 \mathrm{E}-04$ & $\begin{array}{l}502 \\
/ 54 \\
2^{\mathbf{e}}\end{array}$ & $\mathbf{g}$ \\
\hline 86 & $\mathrm{C}_{4} \mathrm{H}_{6} \mathrm{O}_{2}$ & $\mathrm{C}_{4} \mathrm{H}_{6} \mathrm{O}_{2}$ & $\gamma$-Butyrolactone & & ND, NM & 630 & $1.30 \mathrm{E}-04$ & 574 & g \\
\hline 88 & $\mathrm{C}_{4} \mathrm{H}_{8} \mathrm{O}_{2}$ & $\mathrm{C}_{3} \mathrm{H}_{7} \mathrm{OCHO}$ & n-Propyl formate & & ND, NM & 570 & $4.45 \mathrm{E}-05$ & \multirow{2}{*}{498} & \multirow{2}{*}{ g } \\
\hline & & $\mathrm{C}_{3} \mathrm{H}_{7} \mathrm{COOH}$ & Butanoic acid & & ND & 510 & $6.25 \mathrm{E}-03$ & & \\
\hline 102 & $\mathrm{C}_{5} \mathrm{H}_{10} \mathrm{O}_{2}$ & $\mathrm{C}_{4} \mathrm{H}_{9} \mathrm{OCHO}$ & $n$-Butyl formate & & & $590-700^{f}$ & $1.17 \mathrm{E}-04$ & 498 & g \\
\hline 116 & $\mathrm{C}_{6} \mathrm{H}_{12} \mathrm{O}_{2}$ & $\mathrm{C}_{6} \mathrm{H}_{12} \mathrm{O}_{2}$ & $n$-Butyl acetate & & ND, NM & 550 & $3.04 \mathrm{E}-05$ & 498 & g \\
\hline
\end{tabular}


Table 2 (continued)

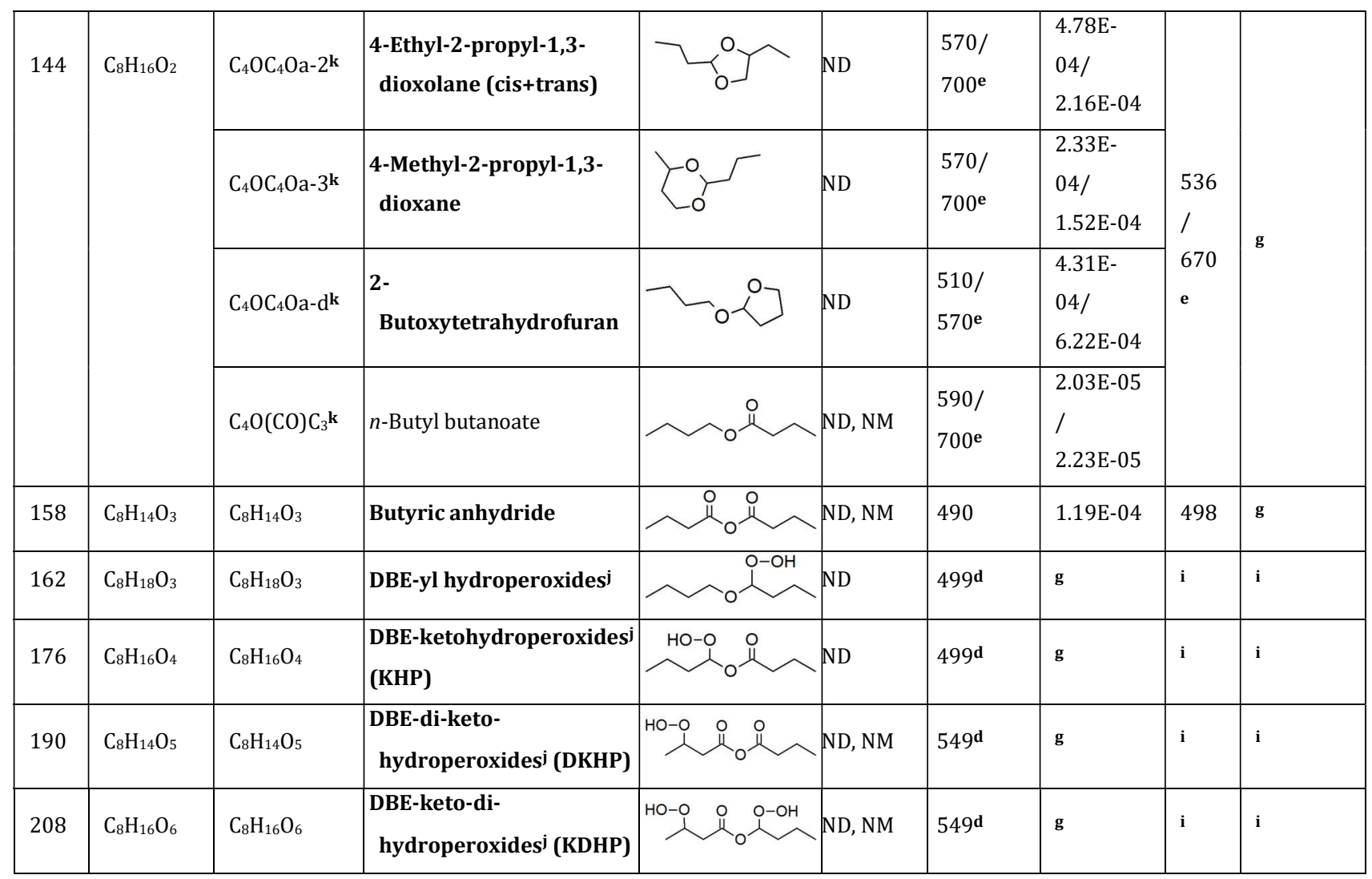

Three general categories of species are observed based on the experimental data.

(i) The first category includes species that reach their maximum mole fraction in the HT region $(>750 \mathrm{~K})$, including methane $\left(\mathrm{CH}_{4}\right)$, ethylene $\left(\mathrm{C}_{2} \mathrm{H}_{4}\right)$, ethane $\left(\mathrm{C}_{2} \mathrm{H}_{6}\right)$, propene $\left(\mathrm{C}_{3} \mathrm{H}_{6}\right)$, ethylene oxide $\left(\mathrm{C}_{2} \mathrm{H}_{4} \mathrm{O} 1,2\right), 1,3$-butadiene $\left(1,3-\mathrm{C}_{4} \mathrm{H}_{6}\right)$, 1-butene $\left(1-\mathrm{C}_{4} \mathrm{H}_{8}\right)$, 2-butene $\left(2-\mathrm{C}_{4} \mathrm{H}_{8}\right)$, acrolein $\left(\mathrm{C}_{2} \mathrm{H}_{3} \mathrm{CHO}\right)$, $n$-butane $\left(\mathrm{nC}_{4} \mathrm{H}_{10}\right)$, and propylene oxide $\left(\mathrm{C}_{3} \mathrm{H}_{6} \mathrm{O} 1,2\right)$. The peak temperatures of these species are consistent between JSR and PFR experiments, apart from $\mathrm{C}_{2} \mathrm{H}_{6}$ for which the peak mole fraction is found at lower temperature in the PFR, probably because of an influence of the formaldehyde peak in the EI-MBMS data evaluation. The species in this category are expected to be produced via either the HT chemistry of DBE or secondary reactions. $\mathrm{C}_{2} \mathrm{H}_{4} \mathrm{O} 1,2$ and $\mathrm{C}_{3} \mathrm{H}_{6} \mathrm{O} 1,2$ exhibit two equivalent maxima in the $\mathrm{HT}$ region and at lower temperatures, indicating that the formation of these species is controlled by both, HT and LT chemistry.

(ii) The second category includes species with maxima in the second NTC zone (JSR: 650$750 \mathrm{~K}$, PFR: $615-750 \mathrm{~K})$. These species are formaldehyde $\left(\mathrm{CH}_{2} \mathrm{O}\right)$, acetaldehyde $\left(\mathrm{CH}_{3} \mathrm{CHO}\right)$, propylene oxide $\left(\mathrm{C}_{3} \mathrm{H}_{6} \mathrm{O} 1,2\right)$, 2-butenal ( $\left.\mathrm{sC}_{3} \mathrm{H}_{5} \mathrm{CHO}\right)$, butanal $\left(\mathrm{nC}_{3} \mathrm{H}_{7} \mathrm{CHO}\right)$, 4-ethyl-2-propyl-1,3dioxolane ( $\left.\mathrm{C}_{4} \mathrm{OC} 4 \mathrm{Oa}-2\right)$, 4-methyl-2-propyl-1,3-dioxane ( $\left.\mathrm{C}_{4} \mathrm{OC}{ }_{4} \mathrm{Oa}-3\right)$, and $n$-butyl butanoate 
$\left(\mathrm{C}_{4} \mathrm{O}(\mathrm{CO}) \mathrm{C}_{3}\right)$. They peak in the second NTC zone, therefore their formation could result from pathways that inhibit the fuel reactivity. Note that $\mathrm{nC}_{3} \mathrm{H}_{7} \mathrm{CHO}, \mathrm{C}_{4} \mathrm{OC}_{4} \mathrm{Oa}-2, \mathrm{C}_{4} \mathrm{OC}_{4} \mathrm{Oa}-3$, and $\mathrm{C}_{4} \mathrm{O}(\mathrm{CO}) \mathrm{C}_{3}$ show further maxima in the lower temperature region.

(iii) The third category includes species with maxima at relatively low temperatures before the occurrence of the second NTC (JSR: <650 K, PFR: <615 K). Apart from propane $\left(\mathrm{C}_{3} \mathrm{H}_{8}\right)$, acetaldehyde $\left(\mathrm{CH}_{3} \mathrm{CHO}\right)$, ethylene oxide $\left(\mathrm{C}_{2} \mathrm{H}_{4} \mathrm{O} 1,2\right)$, ethanol $\left(\mathrm{C}_{2} \mathrm{H}_{5} \mathrm{OH}\right)$, formic acid ( $\left.\mathrm{HCOOH}\right)$, and methyl peroxide $\left(\mathrm{CH}_{3} \mathrm{O}_{2} \mathrm{H}\right)$ these include two $\mathrm{C}_{3} \mathrm{H}_{6} \mathrm{O}$ isomers, namely acetone $\left(\mathrm{CH}_{3} \mathrm{COCH}_{3}\right)$ and propanal $\left(\mathrm{C}_{2} \mathrm{H}_{5} \mathrm{CHO}\right)$. Also, propanol $\left(\mathrm{C}_{3} \mathrm{H}_{7} \mathrm{OH}\right)$, propanoic acid $\left(\mathrm{C}_{2} \mathrm{H}_{5} \mathrm{COOH}\right)$ and two $\mathrm{C}_{4} \mathrm{H}_{8} \mathrm{O}_{2}$ isomers, namely $n$-propyl formate $\left(\mathrm{C}_{3} \mathrm{H}_{7} \mathrm{OCHO}\right)$ and butanoic acid $\left(\mathrm{C}_{3} \mathrm{H}_{7} \mathrm{COOH}\right)$ belong to this category. It includes also butanal $\left(\mathrm{nC}_{3} \mathrm{H}_{7} \mathrm{CHO}\right)$, as well as four $\mathrm{C}_{8} \mathrm{H}_{16} \mathrm{O}_{2}$ isomers, namely 4-ethyl2-propyl-1,3-dioxolane $\quad\left(\mathrm{C}_{4} \mathrm{OC}_{4} \mathrm{Oa}-2\right), \quad$ 4-methyl-2-propyl-1,3-dioxane $\quad\left(\mathrm{C}_{4} \mathrm{OC}_{4} \mathrm{Oa}-3\right)$, 2-butoxytetrahydrofuran $\left(\mathrm{C}_{4} \mathrm{OC}_{4} \mathrm{Oa}-\mathrm{d}\right)$, and $n$-butyl butanoate $\left(\mathrm{C}_{4} \mathrm{O}(\mathrm{CO}) \mathrm{C}_{3}\right)$. Finally, this category encompasses $\mathrm{C}_{8} \mathrm{H}_{14} \mathrm{O}_{3}$ (butyric anhydride), $\mathrm{C}_{8} \mathrm{H}_{18} \mathrm{O}_{3}$, and $\mathrm{C}_{8} \mathrm{H}_{16} \mathrm{O}_{4}$, as well as highly oxygenated intermediates with five and six oxygen atoms $\left(\mathrm{C}_{8} \mathrm{H}_{14} \mathrm{O}_{5}, \mathrm{C}_{8} \mathrm{H}_{16} \mathrm{O}_{6}\right) . \mathrm{C}_{8} \mathrm{H}_{18} \mathrm{O}_{3}, \mathrm{C}_{8} \mathrm{H}_{16} \mathrm{O}_{4}$, $\mathrm{C}_{8} \mathrm{H}_{14} \mathrm{O}_{5}$, and $\mathrm{C}_{8} \mathrm{H}_{16} \mathrm{O}_{6}$ corresponding to nominal masses of DBE-yl hydroperoxides, DBEketohydroperoxides (KHP), DBE-di-keto-hydroperoxides (DKHP), and DBE-keto-dihydroperoxides (KDHP), respectively. Species in this category that reach their maximum mole fractions at very low temperatures $(<580 \mathrm{~K})$ are highlighted in bold font in Table 2 . Among them butanoic acid $\left(\mathrm{C}_{3} \mathrm{H}_{7} \mathrm{COOH}\right)$ was detected in particularly high mole fraction. Since most of these species are newly detected in the present study, they can serve to analyze the LT chemistry of DBE more fully and to extend the validation database for kinetic models.

The further discussion in the next sections will thus focus on selected examples of these newly-detected fuel-specific intermediates. To facilitate orientation, a simplified reaction pathway diagram for DBE, based on the literature mechanisms [12,15], is presented in Figure 3. Starting with the fuel (RH, $m / z$ 130), $\mathrm{H}$-abstractions at different carbon positions (1-4 or a-d) provide the fuel radicals ( $\mathbf{R}, m / z$ 129). $\mathrm{H}$-abstractions at $\mathrm{C}_{\alpha}$ (neighboring the ether group) are expected to be the most important ones because of the lowest $\mathrm{C}-\mathrm{H}$ bond energy at this position ( $95 \mathrm{kcal} \mathrm{mol}^{-1}$ vs. $\sim 99-101 \mathrm{kcal} \mathrm{mol}^{-1}$ at other positions [15]). R can either be decomposed by $\beta$-scission reactions producing $\mathrm{C}_{2} \mathrm{H}_{4}, \mathrm{C}_{3} \mathrm{H}_{6}, \mathrm{C}_{4} \mathrm{H}_{8}-1$, and $\mathrm{nC}_{3} \mathrm{H}_{7} \mathrm{CHO}$ at high temperatures or undergo the first $\mathrm{O}_{2}$ addition yielding DBE-yl-peroxy radicals (RO2, $m / z$ 161) at low temperatures. $\mathrm{RO}_{2}$ can either form DBE-yl hydroperoxides $\left(\mathbf{R O}_{2} \mathbf{H}, m / z 162\right)$ by abstracting an $\mathrm{H}$-atom from other species or isomerize to $\mathbf{Q} \mathbf{O}_{2} \mathbf{H}$ radicals $\left(m / z\right.$ 161). Then, $\mathrm{QO}_{2} \mathrm{H}$ can form $\mathrm{C}_{8} \mathrm{H}_{16} \mathrm{O}_{2}$ cyclic ethers $(\mathrm{m} / \mathrm{z} 144)$, and a second $\mathrm{O}_{2}$-addition on $\mathrm{QO}_{2} \mathrm{H}$ leads to $\mathbf{O}_{2} \mathbf{Q O}_{2} \mathbf{H}$ species 
( $m / z$ 193). By OH-elimination, $\mathrm{O}_{2} \mathrm{QO}_{2} \mathrm{H}$ can form DBE-ketohydroperoxides (KHP, $m / z$ 176) that in turn decompose easily to form a second $\mathrm{OH}$ radical and other species, e.g. $\mathrm{nC}_{3} \mathrm{H}_{7} \mathrm{CHO}, \mathrm{CO}_{2}$, or $\mathrm{C}_{4} \mathrm{H}_{9} \mathrm{OCHO}$. The key species in the primary mechanism of DBE (highlighted by shadowed squares in Figure 3) were experimentally detected in the present study (see Table 2).

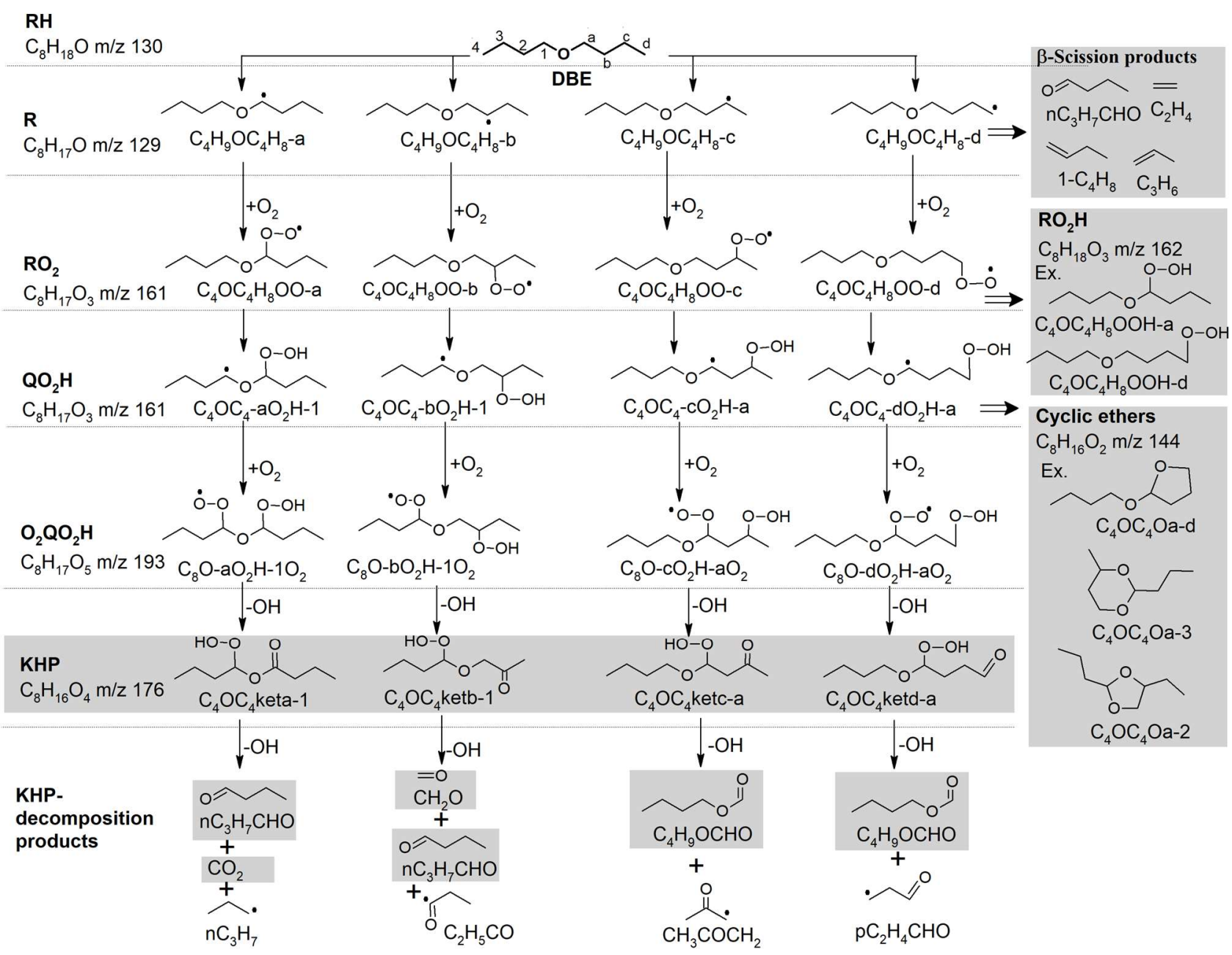

Figure 3. Simplified reaction pathway diagram for DBE LT oxidation at the studied JSR and PFR conditions, based on the literature mechanisms [12,15]. Non-radical intermediates marked by shadowed squares were all detected in the present study, either qualitatively or quantitatively, as described in the text. Note that pathways that might be indicated by the detection of newly-observed species are not yet included here. "Ex.”: Examples of species structure. KHP: DBE-ketohydroperoxides.

\subsubsection{Analysis of the double-NTC behavior}

Species reaching their maximum mole fraction in the first or second NTC regions are expected to play important roles in the occurrence of these zones. Thion et al. [15] used simulations for $\mathrm{nC}_{3} \mathrm{H}_{7} \mathrm{O}_{2} \mathrm{H}$ (propylhydroperoxide) in their explanation of the first NTC region. In the present study, a species at $m / z 76$ was detected experimentally and identified by SVUV-PI-MBMS (see 
Figure S3 in SM2) to be $\mathrm{nC}_{3} \mathrm{H}_{7} \mathrm{O}_{2} \mathrm{H}$ that has a calculated IE of $9.5 \mathrm{eV}$ [31]. Note that another expected peroxide isomer at this mass, i.e. isopropylhydroperoxide $\left(\mathrm{iC}_{3} \mathrm{H}_{7} \mathrm{O}_{2} \mathrm{H}\right)$, has calculated IE of 9.42 [31], but the presence of this species is inconclusive. Normalized signals of this species in Figure 4 reach their maxima in the first NTC region, suggesting an influence of $\mathrm{nC}_{3} \mathrm{H}_{7} \mathrm{O}_{2} \mathrm{H}$ formation routes on its occurrence. Other fuel-specific species with peaks in the first NTC zone (see Figure 4) include $\mathrm{nC}_{3} \mathrm{H}_{7} \mathrm{CHO}$ (butanal) and $\mathrm{C}_{8} \mathrm{H}_{16} \mathrm{O}_{2}$ (cyclic ethers); note that the two latter species also contribute to the second NTC zone.
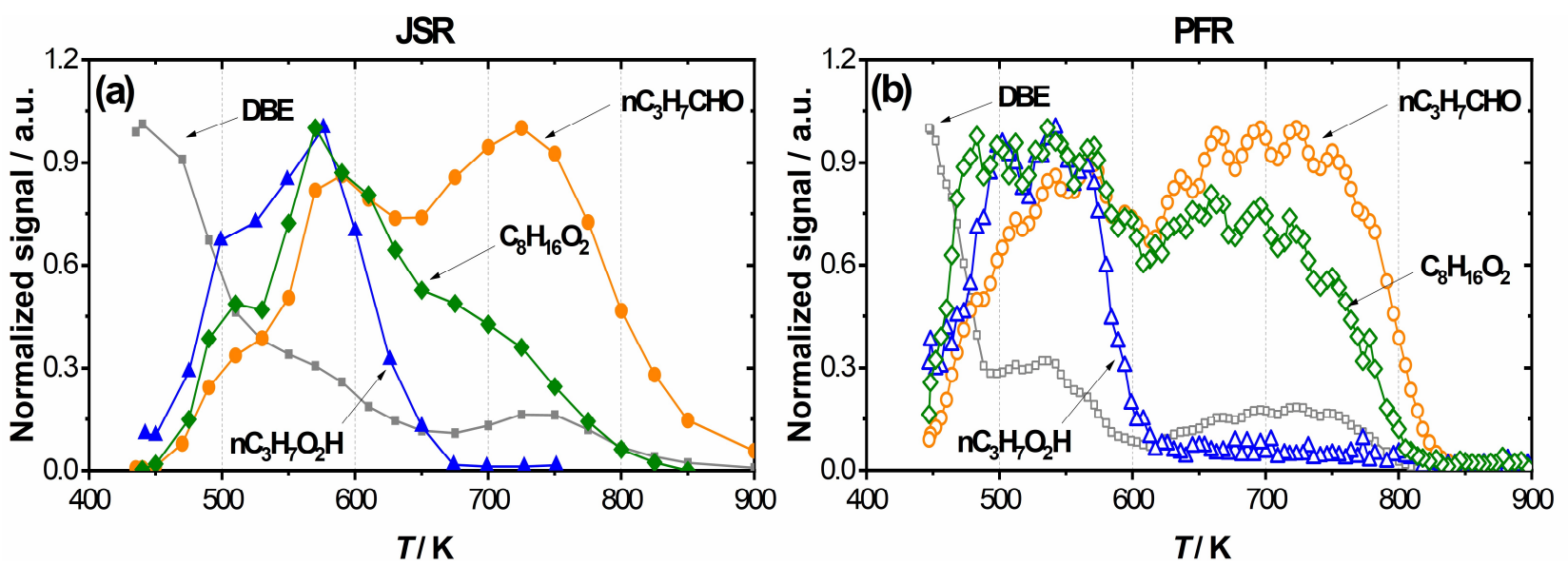

Figure 4. Experimental signal profiles of species reaching their maxima in the first or second NTC zone.

Left: JSR, right: PFR. These species are $\mathrm{nC}_{3} \mathrm{H}_{7} \mathrm{O}_{2} \mathrm{H}$ (propylhydroperoxide), $\mathrm{C}_{8} \mathrm{H}_{16} \mathrm{O}_{2}$ (sum of cyclic ethers), and $\mathrm{C}_{4} \mathrm{H}_{8} \mathrm{O}$ (butanal). DBE profiles are added to track the fuel reactivity. Profiles are normalized by the highest value for clarity.

Based on the structure of DBE and indications from the present experimental results, a mechanism for the origin of the two NTC zones is proposed in Figure 5. Here, only reaction paths starting from the $\mathrm{C}_{4} \mathrm{H}_{9} \mathrm{OC}_{4} \mathrm{H}_{8}$-a radical are shown because these are the most important consumption routes of DBE.

At temperatures below the first NTC zone (JSR: $<525 \mathrm{~K}, \mathrm{PFR}:<500 \mathrm{~K}$ ), $\mathrm{C}_{4} \mathrm{H}_{9} \mathrm{OC}_{4} \mathrm{H}_{8}$-a can largely react by $\mathrm{O}_{2}$ addition ( $r 1$, first $\mathrm{O}_{2}$ addition). The resulting $\mathrm{C}_{4} \mathrm{OC}_{4}-\mathrm{aO}_{2} \mathrm{H}-1$ radical then reacts by the second $\mathrm{O}_{2}$ addition ( $r 2$ ) to produce two $\mathrm{OH}$ radicals and the $\mathrm{nC}_{3} \mathrm{H}_{7}$ radical (through some intermediate steps), increasing the system's reactivity. This reaction route involves also the formation of $\mathrm{nC}_{3} \mathrm{H}_{7} \mathrm{CHO}$ and $\mathrm{nC}_{3} \mathrm{H}_{7} \mathrm{O}_{2} \mathrm{H}$ (via the LT chemistry of $\mathrm{nC}_{3} \mathrm{H}_{7}$ [15], Figure 5), explaining the detection of these species at relatively low temperatures (Figure 4). With increasing temperature (JSR: 525-575 K, PFR: 500-545 K), the thermal decomposition reactions of $\mathrm{C}_{4} \mathrm{OC}_{4}$ $\mathrm{aO}_{2} \mathrm{H}-1$ ( $r 3$ and $r 4$ ) can compete with reaction $r 2$, reducing the reactivity and leading to the first NTC zone. Reactions $r 3$ or $r 4$ produce only one $\mathrm{OH}$ radical and stable species, i.e. $\mathrm{C}_{8} \mathrm{H}_{16} \mathrm{O}_{2}$ cyclic 
ethers and two $\mathrm{nC}_{3} \mathrm{H}_{7} \mathrm{CHO}$ molecules. $\mathrm{nC}_{3} \mathrm{H}_{7} \mathrm{CHO}$, which was detected in very high amounts (see Table 2), can in turn react to produce $\mathrm{nC}_{3} \mathrm{H}_{7} \mathrm{O}_{2} \mathrm{H}$. The measured profiles of $\mathrm{C}_{8} \mathrm{H}_{16} \mathrm{O}_{2}, \mathrm{nC}_{3} \mathrm{H}_{7} \mathrm{CHO}$, and $\mathrm{nC}_{3} \mathrm{H}_{7} \mathrm{O}_{2} \mathrm{H}$, which show their peak mole fraction in the first NTC zone (Figure 4) support these reaction channels. At even higher temperatures (JSR: 575-650 K, PFR: 545-615 K), $\mathrm{nC}_{3} \mathrm{H}_{7} \mathrm{O}_{2} \mathrm{H}$ can decompose to form $\mathrm{OH}$ as demonstrated in [15], increasing the system's reactivity. With further increasing temperatures (JSR: 650-750 K, PFR: 615-750 K), the decomposition of the fuel radical to $\mathrm{nC}_{3} \mathrm{H}_{7} \mathrm{CHO}$ and the $\mathrm{PC}_{4} \mathrm{H}_{9}$ radical (reaction $r 5$ ) is favored and competes with the first $\mathrm{O}_{2}$ addition (reaction $r 1$ ), leading to a decrease of the reactivity and the occurrence of the second NTC zone. The profiles of $\mathrm{nC}_{3} \mathrm{H}_{7} \mathrm{CHO}$ (Figure 4) underline the role of reaction $r 5$ in this temperature range.

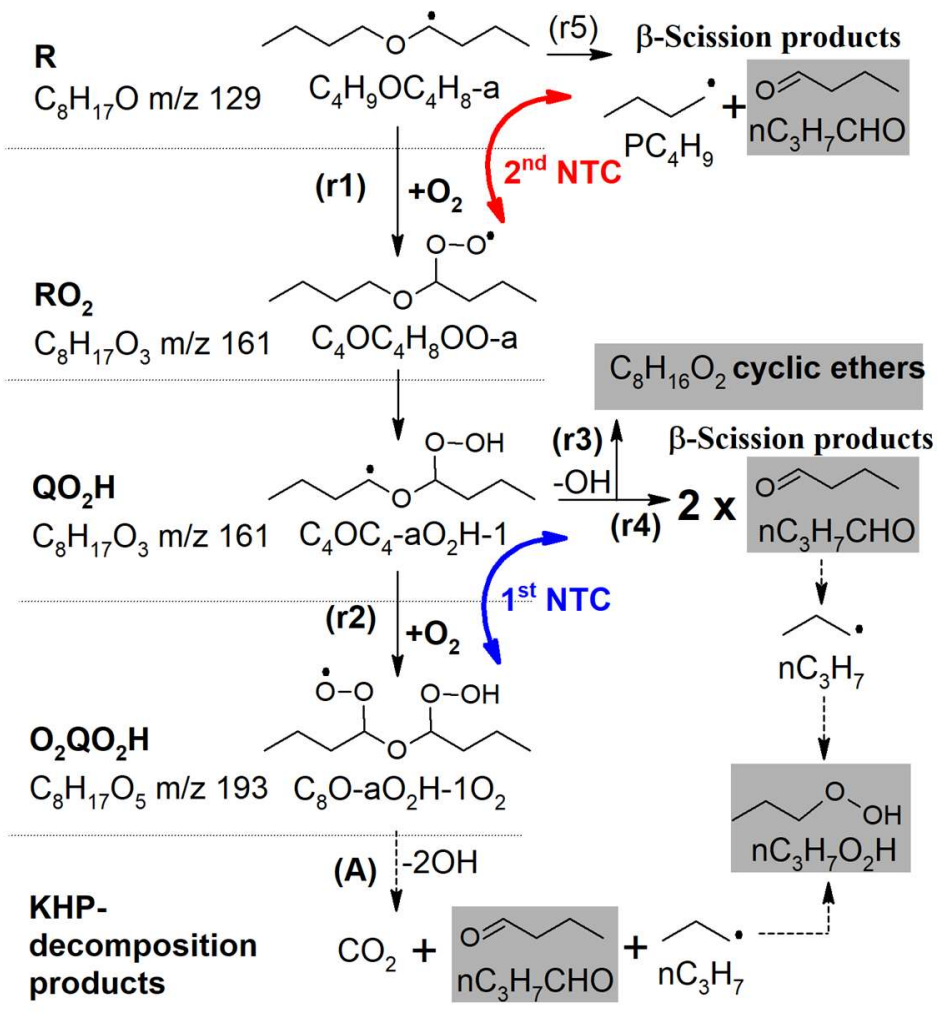

Figure 5. Proposed mechanism of DBE oxidation resulting in two NTC zones. Dashed arrows represent series of reactions. Products of reaction channel (A) are based on Figure 3; this channel can produce other important intermediates as discussed later in the text.

\subsubsection{Newly-identified fuel-specific stable intermediates}

Among newly-detected stable intermediates, acids, fuel-specific cyclic ethers and diones were identified. 


\subsubsection{Acids}

While formic acid (HCOOH) was also previously observed by Thion et al. [15], we additionally report detection of larger acids as shown in Figure 6, including acetic acid $\left(\mathrm{CH}_{3} \mathrm{COOH}\right)$, propanoic acid $\left(\mathrm{C}_{2} \mathrm{H}_{5} \mathrm{COOH}\right)$, and butanoic acid $\left(\mathrm{C}_{3} \mathrm{H}_{7} \mathrm{COOH}\right)$, independently identified by GC-MS and PI-MBMS. The PIE curves obtained at $500 \mathrm{~K}$ for $\mathrm{m} / z 60$ and $\mathrm{m} / z 88$ (Figure $6 \mathrm{a}, \mathrm{b}$ ) correspond to the nominal mass of the two most abundant acids $\mathrm{CH}_{3} \mathrm{COOH}$ and $\mathrm{C}_{3} \mathrm{H}_{7} \mathrm{COOH}$ and show onsets near the ionization energy (IE) of acetic acid ( 10.65 eV [32]) (Figure 6a) and butanoic acid (10.17 eV [32]) (Figure 6b). Note that after identification by PI-MBMS and GC-MS, both species at $\mathrm{m} / \mathrm{z} 88$ labeled in Figure $6 \mathrm{~b}$ have been quantified by GC, thus their mole fractions do not rely on quantification by PI-MBMS and potential uncertainties of cross sections.
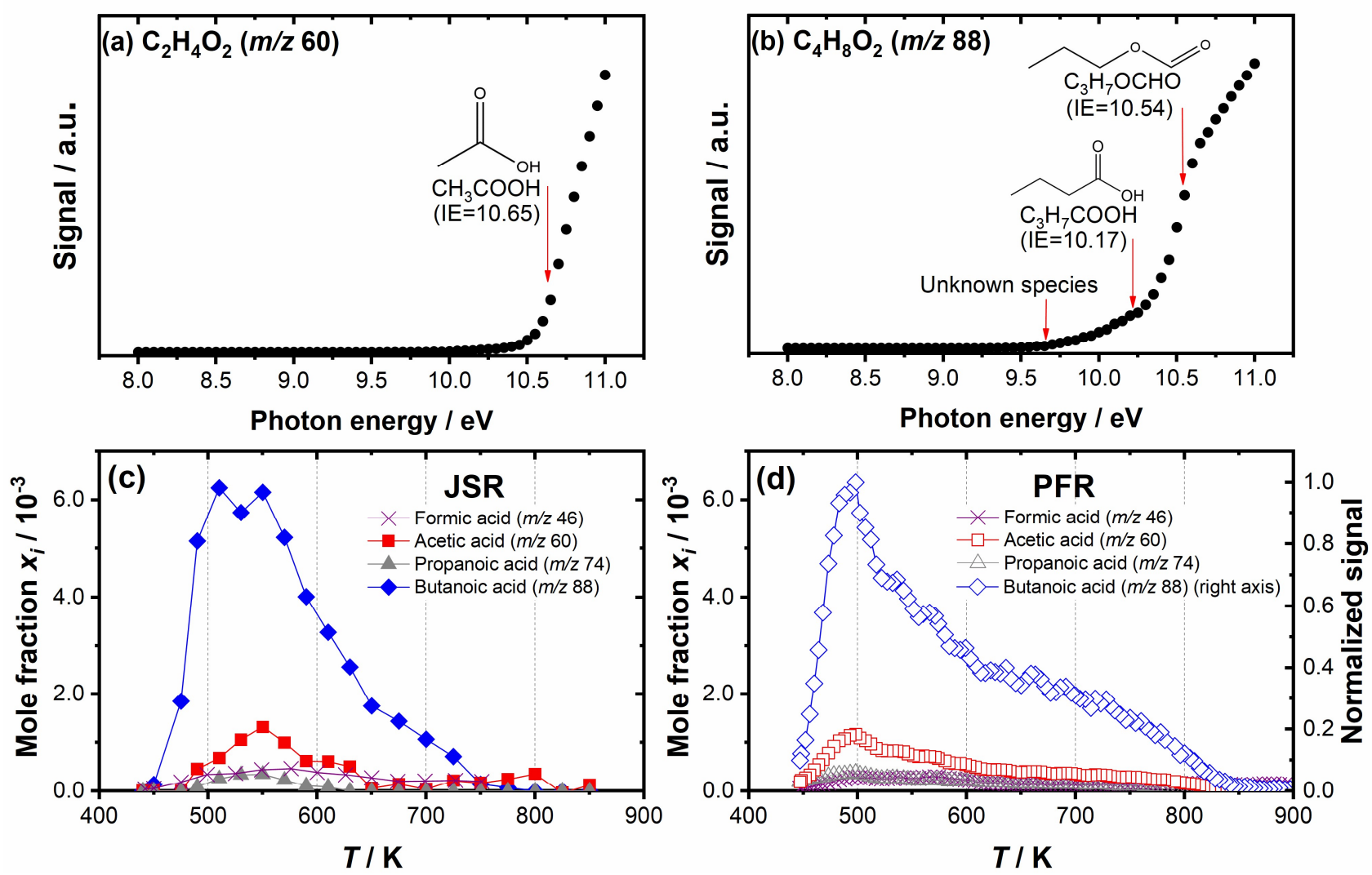

Figure 6. PIE curves at $500 \mathrm{~K}$ from the JSR-PI-MBMS experiment for $m / z 60$ (a) and 88 (b), corresponding to acetic acid $\left(\mathrm{CH}_{3} \mathrm{COOH}\right)$ and butanoic acid $\left(\mathrm{C}_{3} \mathrm{H}_{7} \mathrm{COOH}\right)$, respectively. Profiles of the detected acids; (c) JSR, (d) PFR.

Figure $6 c$,d presents the mole fraction profiles of the detected acids which show their maxima predominantly below the first NTC zone (apart from formic acid). Butanoic acid shows the largest concentration not only compared to the other acids in Figure 6, but among all detected 
intermediates in the LT range $(<650 \mathrm{~K}$, Table 2$)$, indicating its paramount role in the LT oxidation of DBE. Formation paths of this acid from DBE have not yet been discussed in the literature. A more detailed comparison showing good agreement between the three experiments for $m / z 88$ (butanoic acid) is presented in Figure S4 in SM2. In both reactor configurations, the profiles of this species increase very quickly and peak at relatively low temperature (JSR: 510 K, PFR: 498 $\mathrm{K})$. The peak is narrower in the PFR, consistent with the fuel profiles in Figure 1c.

\subsubsection{2 $\mathrm{C}_{8} \mathrm{H}_{16} \mathrm{O}_{2}$ cyclic ethers}

Fuel-specific $\mathrm{C}_{8} \mathrm{H}_{16} \mathrm{O}_{2}$ cyclic ethers can be produced from the $\mathrm{QO}_{2} \mathrm{H}$ radicals during the oxidation of DBE as described earlier (compare Figure 3), but they had previously not been observed experimentally. Figure 7 presents experimental evidence for $\mathrm{C}_{8} \mathrm{H}_{16} \mathrm{O}_{2}$ species that were consistently detected in all three setups. The profiles of the sums of isomers depicted in Figure 7 agree reasonably well in shape and position of the individual peaks at around $500 \mathrm{~K}, 550 \mathrm{~K}$, and $700 \mathrm{~K}$, with some differences between JSR and PFR experiments.

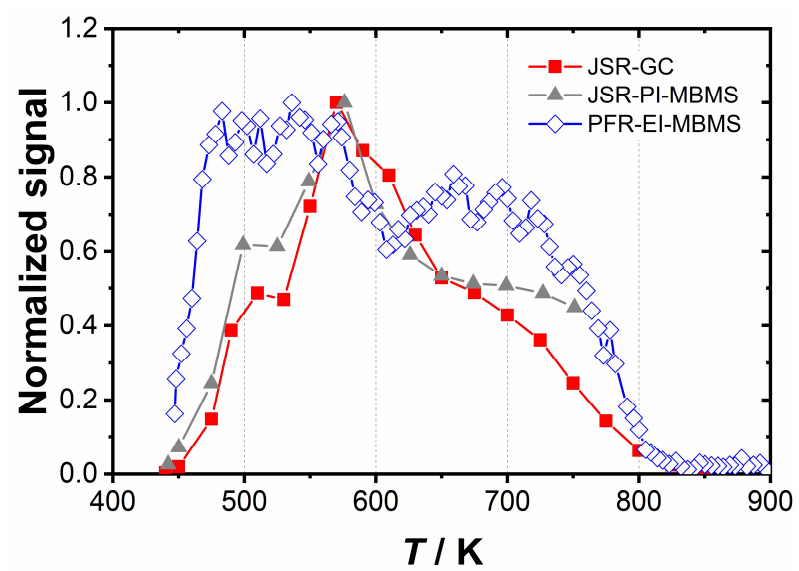

Figure 7. Experimental profiles of the sum of $\mathrm{C}_{8} \mathrm{H}_{16} \mathrm{O}_{2}$ isomers from the three reactor experiments, normalized to the maximum signal in each case.

Because of its long chain, the oxidation of DBE could lead to several isomeric structures of $\mathrm{C}_{8} \mathrm{H}_{16} \mathrm{O}_{2}$. However, in the absence of the relevant IEs, their identification has been very challenging. Zero-point-energy-corrected adiabatic IEs of expected isomers were therefore calculated from the composite CBS-QB3 method [33] using Gaussian [34]. The IE for $n$-butyl formate which is available from [32] was calculated with the same method for reference. The results are summarized in Table 3. Generally, IEs of these species were calculated to be in the range of 9.05-9.40 eV with an estimated uncertainty of $0.1 \mathrm{eV}$. 
Table 3. Calculated IEs of the expected $\mathrm{C}_{8} \mathrm{H}_{16} \mathrm{O}_{2}$ isomers. (The IE of $\mathrm{C}_{5} \mathrm{H}_{10} \mathrm{O}_{2}$ was calculated with the same method for reference). *From NIST [32].

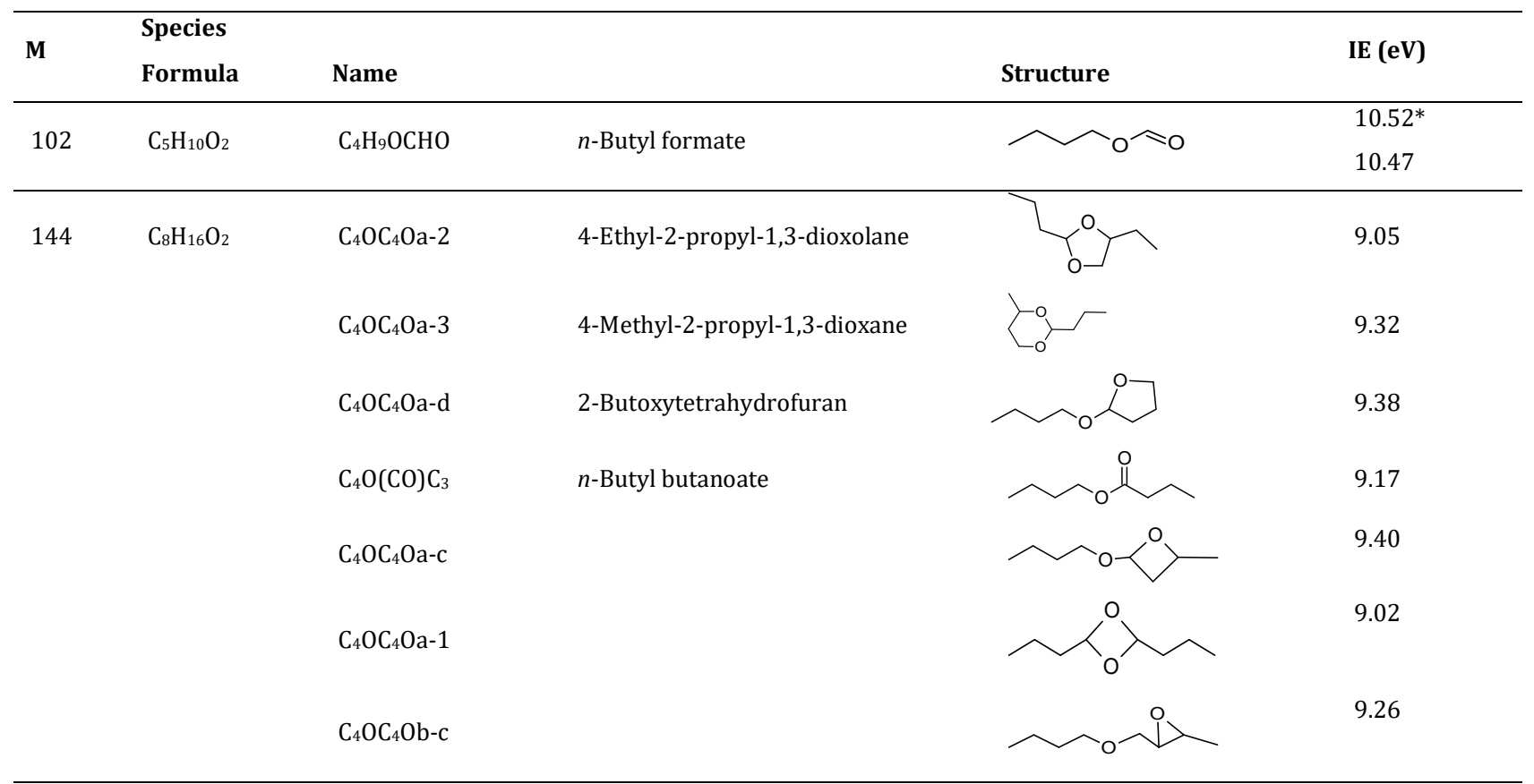

Figure 8 provides more detailed information on the analysis of the $\mathrm{C}_{8} \mathrm{H}_{16} \mathrm{O}_{2}$ species, with PIE curves from PI-MBMS (a), mass spectra from GC-MS detection (b), and quantitative mole fraction profiles (c). The PIE spectrum (Figure 8a) shows a small rise of the signal near $\sim 9 \mathrm{eV}$ followed by a more pronounced one starting near $\sim 9.3 \mathrm{eV}$, indicating the presence of $\mathrm{C}_{8} \mathrm{H}_{16} \mathrm{O}_{2}$ isomers listed in Table 3. The rather small differences in their calculated IEs, however, preclude unambiguous identification. More accurate theoretical methods are known to be useful for calculations of absolute IE values as pointed out by Moshammer et al. [35], which are beyond the scope of the present study, however. Rather, an experimental discrimination between important isomers by GC-MS seemed to be a more direct way of solving this problem. With the GC-MS experiment, four $\mathrm{C}_{8} \mathrm{H}_{16} \mathrm{O}_{2}$ isomers were detected, namely $n$-butyl butanoate $\left(\mathrm{C}_{4} \mathrm{O}(\mathrm{CO})_{3}\right)$ and three cyclic ethers, i.e. cis/trans 4-ethyl-2-propyl-1,3-dioxolane ( $\left.\mathrm{C}_{4} \mathrm{OC} 4 \mathrm{Oa}-2\right)$, 4-methyl-2propyl-1,3-dioxane $\left(\mathrm{C}_{4} \mathrm{OC}{ }_{4} \mathrm{Oa}-3\right)$, and 2-butoxytetrahydrofuran $\left(\mathrm{C}_{4} \mathrm{OC}_{4} \mathrm{Oa}-\mathrm{d}\right)$. They are thus expected to be the most abundant $\mathrm{C}_{8} \mathrm{H}_{16} \mathrm{O}_{2}$ isomers. While $\mathrm{C}_{4} \mathrm{OC}_{4} \mathrm{Oa}-\mathrm{d}$ can be identified from the reference mass spectrum in the NIST library [32], those of $\mathrm{C}_{4} \mathrm{OC}_{4} \mathrm{Oa}-2$ and $\mathrm{C}_{4} \mathrm{OC}_{4} \mathrm{Oa}-3$ are not available. The identification of those species was thus derived from their fragmentation reactions (compare SM2, Figure S5). Accordingly, fragments at $m / z 101$ should be seen for $\mathrm{C}_{4} \mathrm{OC}_{4} \mathrm{Oa}-2$ and $\mathrm{C}_{4} \mathrm{OC}_{4} \mathrm{Oa}-3$. However, differences in the peak intensity are observed, since the fragmentation of the six-membered ring structure includes reactions, initiated by a ring opening (also giving rise to further fragments) which is not equally preferred for the five-membered ring 
structure. As evident from the mass spectra in Figure 8b, assignment of these three cyclic ethers could be confirmed. The four identified $\mathrm{C}_{8} \mathrm{H}_{16} \mathrm{O}_{2}$ isomers were then quantified in the $\mathrm{GC}$ experiment and their profiles (Figure 8c) exhibit peak mole fractions in the order $\mathrm{C}_{4} \mathrm{OC}_{4} \mathrm{Oa}-\mathrm{d}>$ $\mathrm{C}_{4} \mathrm{OC}_{4} \mathrm{Oa}-2>\mathrm{C}_{4} \mathrm{OC}_{4} \mathrm{Oa}-3>\mathrm{C}_{4} \mathrm{O}(\mathrm{CO}) \mathrm{C}_{3}$, suggesting that their total production rate from the $\mathrm{QO}_{2} \mathrm{H}$ radicals (Figure 3 ) might also be expected in that order.
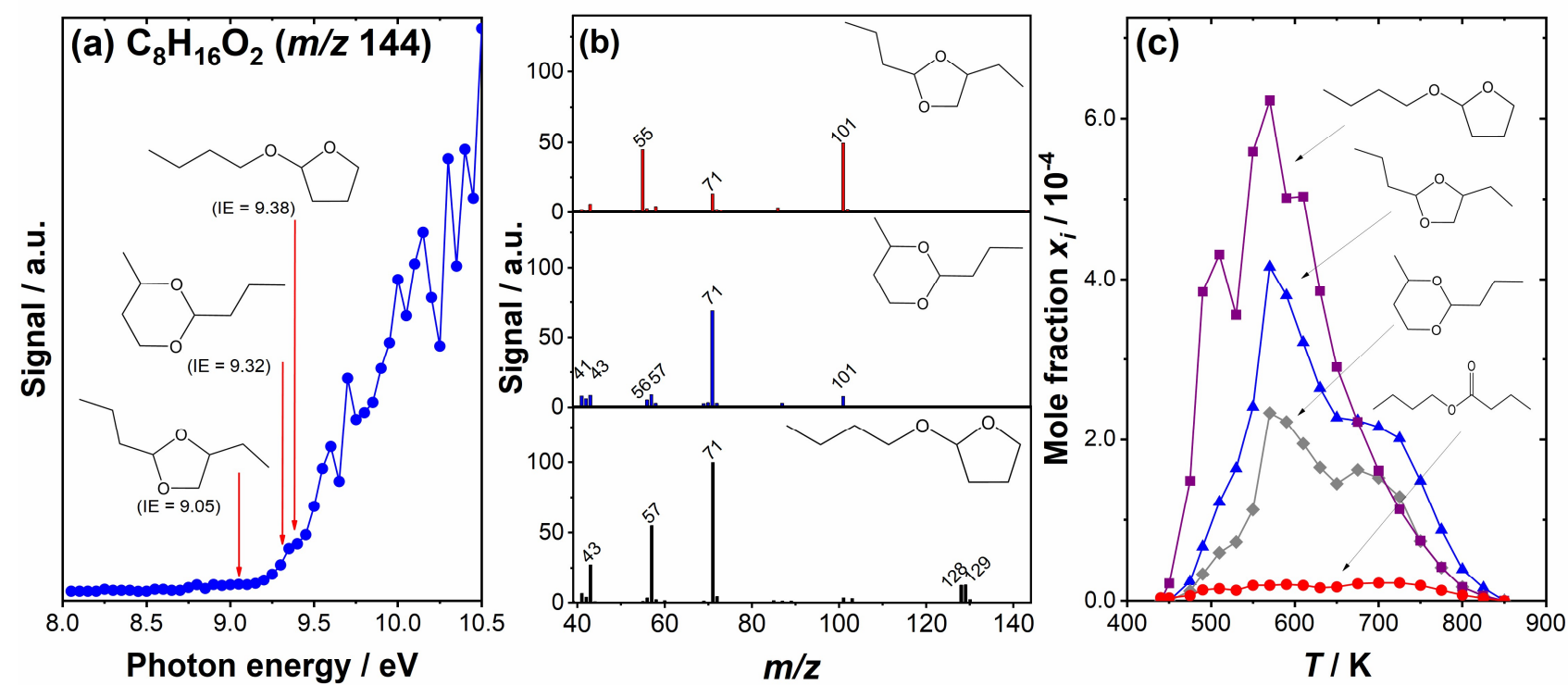

Figure 8. (a) PIE curves for the $\mathrm{C}_{8} \mathrm{H}_{16} \mathrm{O}_{2}$ cyclic ethers, (b) fragmentation mass spectra from GC-MS, (c) mole fraction profiles of the $\mathrm{C}_{8} \mathrm{H}_{16} \mathrm{O}_{2}$ isomers identified by the JSR-GC experiments.

\subsubsection{Diones $\left(\mathrm{C}_{8} \mathrm{H}_{14} \mathrm{O}_{3}, \mathrm{~m} / \mathrm{z}\right.$ 158)}

Diones feature two carbonyl groups, and several fuel-specific diones could be formed from DBE considering its long carbon chain. However, only butyric anhydride $\left(\mathrm{C}_{8} \mathrm{H}_{14} \mathrm{O}_{3}\right)$ was detected here, possibly as the most abundant dione. The profiles of $\mathrm{C}_{8} \mathrm{H}_{14} \mathrm{O}_{3}$ from JSR and PFR in Figure 9 agree well in shape and consistently reach their maxima at very low temperature $(\sim 495 \mathrm{~K})$. It is thus expected that this previously unobserved species could play an important role in the LT chemistry of DBE, although it is currently not included in the models $[12,15]$. 


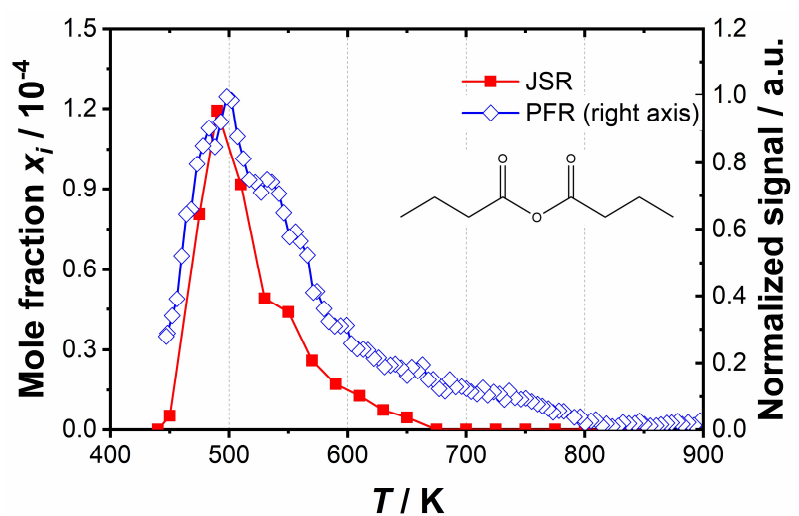

Figure 9. Experimental profiles of $\mathrm{C}_{8} \mathrm{H}_{14} \mathrm{O}_{3}$ (butyric anhydride) measured in JSR and PFR.

\subsubsection{Newly-detected highly-oxygenated reactive intermediates}

Reactive oxygenated intermediates such as hydroperoxides were detected here owed to the used MBMS technique. Applications of the latter technique in hydroperoxide analyses were recently summarized in a review paper by Wang et al. [36]. In the present study, methyl peroxide $\left(\mathrm{CH}_{3} \mathrm{O}_{2} \mathrm{H}\right)$ and propylhydroperoxide $\left(\mathrm{nC}_{3} \mathrm{H}_{7} \mathrm{O}_{2} \mathrm{H}\right)$ were experimentally identified and quantified with mole fractions of $1.95 \times 10^{-04}$ and $2.78 \times 10^{-04}$, respectively (Table 2 ). For heavier species, molecular formulae were proposed based on the measured signals at the respective $m / z$ ratio. These signals at $m / z$ ratios of $162,176,190$, and 208 detected only in the LT regime are identified as significantly oxidized species with 3-6 oxygen atoms, and are assigned as $\mathrm{C}_{8} \mathrm{H}_{18} \mathrm{O}_{3}, \mathrm{C}_{8} \mathrm{H}_{16} \mathrm{O}_{4}, \mathrm{C}_{8} \mathrm{H}_{14} \mathrm{O}_{5}$, and $\mathrm{C}_{8} \mathrm{H}_{16} \mathrm{O}_{6}$, respectively; they have the same number of carbons as those in fuel. Figure 10 presents the profiles of these species, measured in the JSR-PI-MBMS experiments. This figure shows that these profiles peak at relatively low temperatures. Example of the PIE curves obtained for highly-oxygenated species containing 5 and 6 oxygen atoms are shown in Figure S6 (SM2) that shows the onsets at around $9.15 \mathrm{eV}$ and $9.25 \mathrm{eV}$, respectively. Several isomers could be present at these masses. However, their complexity and the unavailability of their IE and cross sections refrain definitive assignments for the structure of these species. By speculation based on fuel structure and on its LT chemistry together with the obtained experimental signals, $\mathrm{C}_{8} \mathrm{H}_{18} \mathrm{O}_{3}, \mathrm{C}_{8} \mathrm{H}_{16} \mathrm{O}_{4}, \mathrm{C}_{8} \mathrm{H}_{14} \mathrm{O}_{5}$, and $\mathrm{C}_{8} \mathrm{H}_{16} \mathrm{O}_{6}$ could include fuel hydroperoxides $\left(\mathrm{RO}_{2} \mathrm{H}\right)$, fuel keto-hydroperoxides (KHP), di-keto-hydroperoxides (DKHP), and keto-di-hydroperoxides (KDHP), respectively, with examples of their possible structure shown in Figure 10. $\mathrm{RO}_{2} \mathrm{H}$ and $\mathrm{KHP}$ correspond to the products of the first and second $\mathrm{O}_{2}$ addition, respectively (see Figure 3). The signal profiles of these species exhibit two peaks, near $\sim 500 \mathrm{~K}$ and $\sim 570 \mathrm{~K}$, indicating that these species could contribute to the increase of the system's reactivity noted in this temperature regime (compare Figure 1). The detected highlyoxygenated species $\left(\mathrm{C}_{8} \mathrm{H}_{14} \mathrm{O}_{5}\right.$, and $\left.\mathrm{C}_{8} \mathrm{H}_{16} \mathrm{O}_{6}\right)$ corresponding to the nominal masses of DKHP and 
KDHP could indicate the potential importance of the third $\mathrm{O}_{2}$ addition chemistry that is, however, not yet included in current kinetic models of DBE. This chemistry is expected to be favorable because of the influence of the ether oxygen atom of DBE together with its long carbon chains, as will be discussed in Section 3.4.
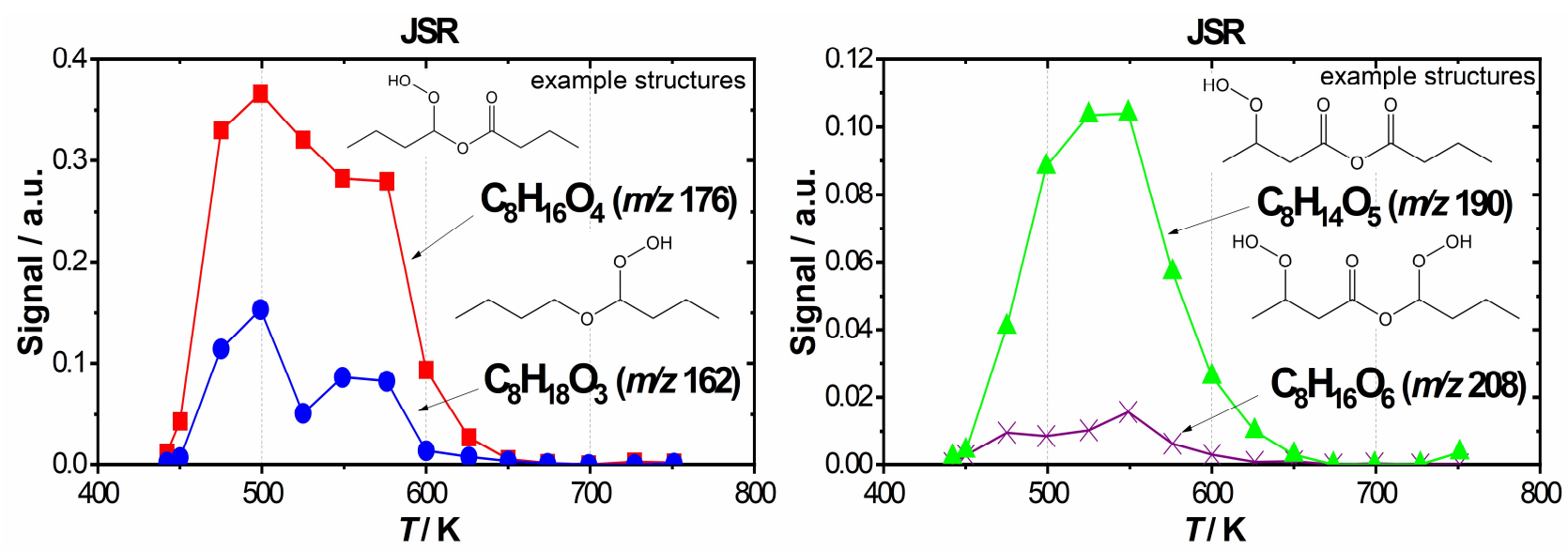

Figure 10. Profiles of highly-oxygenated species from JSR-PI-MBMS experiments: $\mathrm{C}_{8} \mathrm{H}_{18} \mathrm{O}_{3}$ (tentatively assigned as hydroperoxide products of the first $\mathrm{O}_{2}$ addition), $\mathrm{C}_{8} \mathrm{H}_{16} \mathrm{O}_{4}$ (tentatively assigned as keto-

hydroperoxide products of the second $\mathrm{O}_{2}$ addition), $\mathrm{C}_{8} \mathrm{H}_{14} \mathrm{O}_{5}$ and $\mathrm{C}_{8} \mathrm{H}_{16} \mathrm{O}_{6}$ (tentatively assigned, respectively, as di-keto-hydroperoxide and keto-di-hydroperoxide products of the third $\mathrm{O}_{2}$ addition).

Examples of species structures are included.

\subsection{Comparison of experiments and models}

Speciation measurements obtained in the present study have been used here as valuable targets for the recent DBE kinetic mechanisms by Thion et al. [15] and Cai et al. [12]. Selected species are presented and discussed below, while further profiles including major species are given in SM2. Both models can well predict the fuel consumption and product formation below $500 \mathrm{~K}$ and above $800 \mathrm{~K}$ as evident from $\mathrm{DBE}$ and $\mathrm{CO}_{2}$ profiles for both reactor configurations (see Figure S7 in SM2). The model prediction is very different between 500 and $800 \mathrm{~K}$, however, which may be due to differences in the used rate coefficients as described in Section 2.4.

Selected $\mathrm{C}_{2}-\mathrm{C}_{5}$ species that were previously also observed by Thion et al. [15] are presented in Figure 11, including $\mathrm{C}_{2} \mathrm{H}_{4}$ and $\mathrm{C}_{4} \mathrm{H}_{8}$ as decomposition products of the fuel radicals and $\mathrm{C}_{4} \mathrm{H}_{9} \mathrm{OCHO}$ as products of KHP decomposition (compare Figure 3). Overall, regarding also the substantial number of further species profiles given in Figures S7-S13 in SM2, the two models reproduce many features of the LT chemistry in both reactor configurations reasonably well. A 
closer inspection of Figure 11 reveals some discrepancies in the predictions between the two models, however, concerning in particular, $\mathrm{C}_{4} \mathrm{H}_{9} \mathrm{OCHO}$ for which the Thion model predicts substantially higher mole fractions than the Cai model. These differences most probably stem from the use of different rate coefficients for the formation routes $\left(\mathrm{O}_{2} \mathrm{QO}_{2} \mathrm{H}=\mathrm{OH}+\mathrm{KHP}\right)$ of two KHPs $\left(\mathrm{C}_{4} \mathrm{OC}_{4}\right.$ ketc-a and $\mathrm{C}_{4} \mathrm{OC}_{4}$ ketd-a) that are responsible for the formation of $\mathrm{C}_{4} \mathrm{H}_{9} \mathrm{OCHO}$ (compare Fig 3). Note that both models predict the peak position of the KHP profiles $\left(\mathrm{C}_{8} \mathrm{H}_{16} \mathrm{O}_{4}\right.$, sums of isomers) quite well, although their simulated mole fractions are very different (Figure S13).
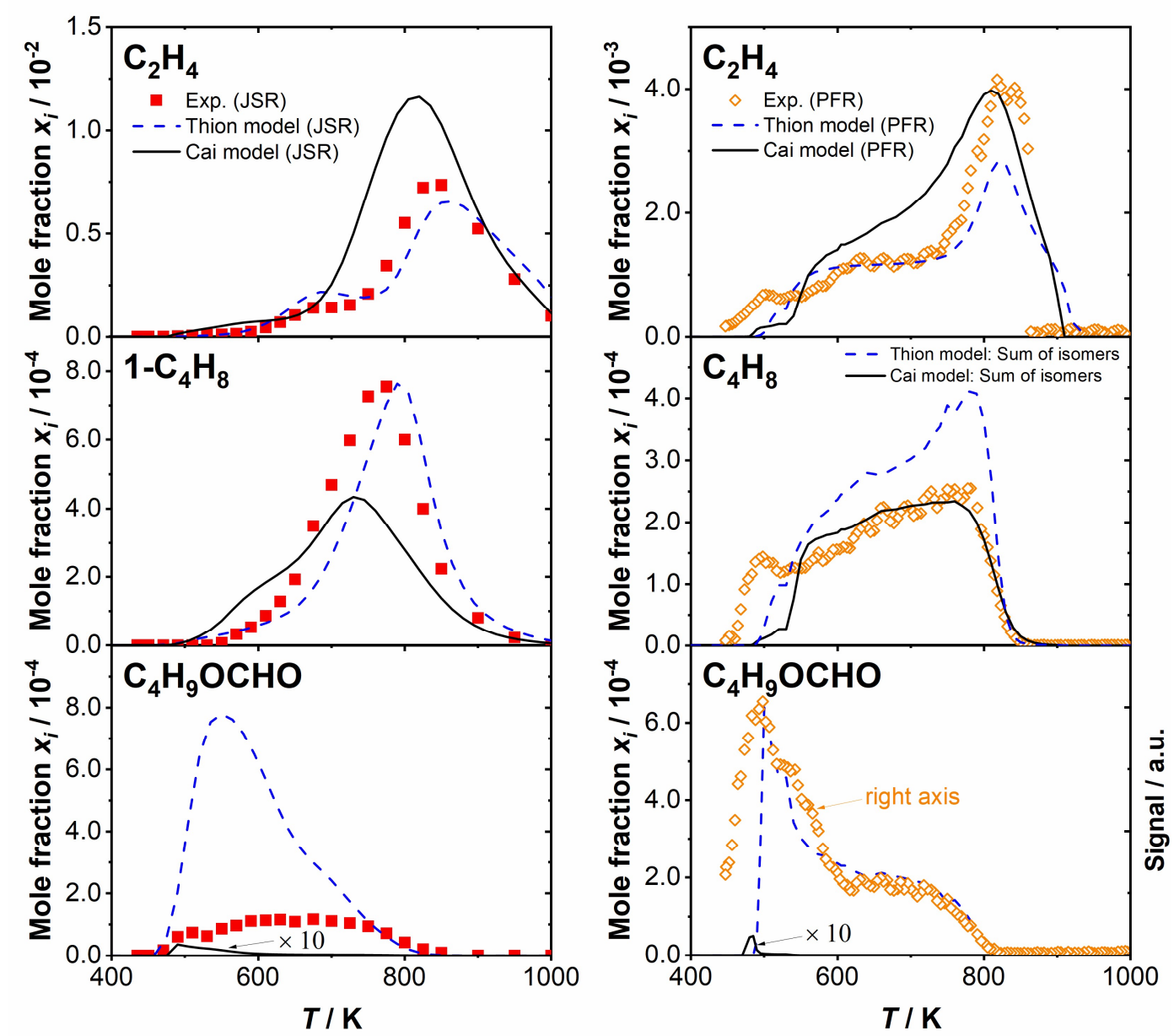

Figure 11. Experimental results and model predictions $[12,15]$ for selected intermediate species. Left: JSR, right: PFR.

Figures 12 and 13 present selected intermediates that were not observed experimentally in [15]; those are butanoic acid $\left(\mathrm{C}_{3} \mathrm{H}_{7} \mathrm{COOH}\right.$, Figure 12), the most abundant LT intermediate species (compare Table 2), and three $\mathrm{C}_{8} \mathrm{H}_{16} \mathrm{O}_{2}$ cyclic ethers (Figure 13), products of $\mathrm{QO}_{2} \mathrm{H}$ decomposition (compare Figure 3). In general, the models cannot predict the formation of the newly-detected species satisfactorily. For example, while $\mathrm{C}_{3} \mathrm{H}_{7} \mathrm{COOH}$ is not present in the Cai 
model, it is included in the Thion model but its formation is significantly under-predicted (Figure 12). However, this latter model predicts very well the peak position, indicating that the formation of $\mathrm{C}_{3} \mathrm{H}_{7} \mathrm{COOH}$ starting from $\mathrm{KHP}$ (as proposed in the Thion model: $\mathrm{C}_{4} \mathrm{OC}_{4}$ keta- $1=>\mathrm{C}_{3} \mathrm{H}_{7} \mathrm{COOH}+\mathrm{C}_{3} \mathrm{H}_{8}+\mathrm{CO}_{2}$ ) is plausible, but other formation routes of $\mathrm{C}_{3} \mathrm{H}_{7} \mathrm{COOH}$ starting also from KHP are probably missing, as will be discussed in Section 3.4. For other acids, the Thion model reproduces the mole fraction profiles of formic acid ( $\mathrm{HCOOH})$ well, while the Cai model over-predicts the concentration of this species (Figure S8). Both models underpredict the formation of acetic acid $\left(\mathrm{CH}_{3} \mathrm{COOH}\right.$, Figure S9). Propanoic acid has not been included in these models.
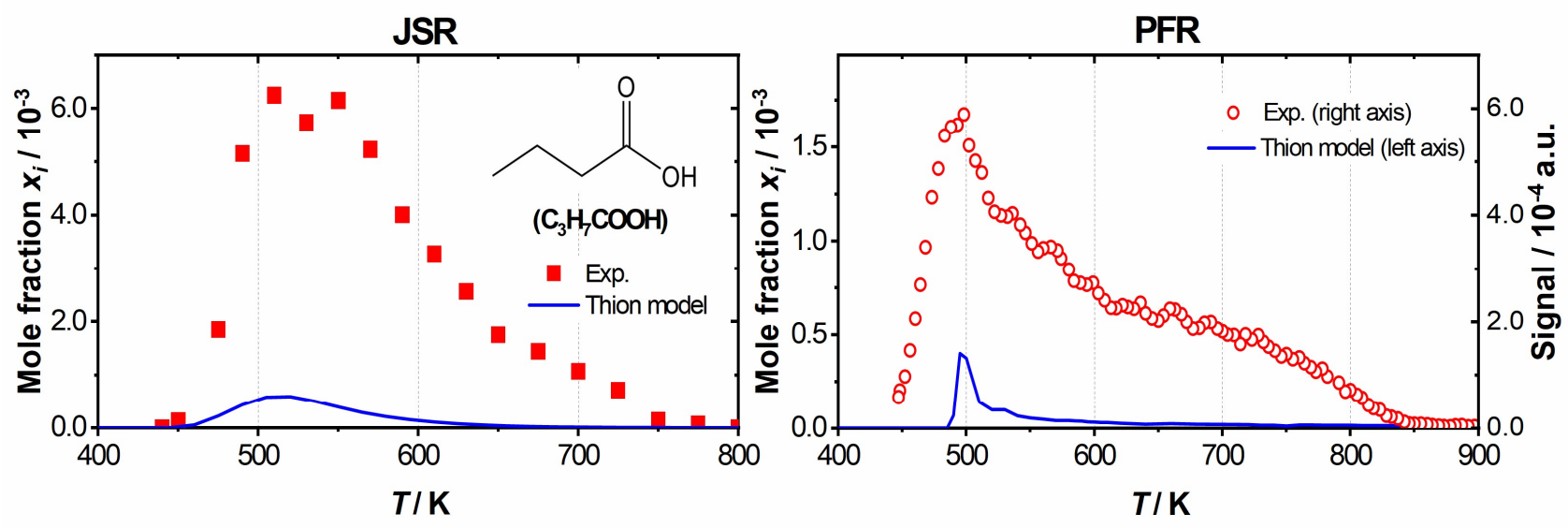

Figure 12. Experimental results and model predictions [15] for butanoic acid $\left(\mathrm{C}_{3} \mathrm{H}_{7} \mathrm{COOH}\right)$. Left: JSR, Right: PFR.

Regarding the $\mathrm{C}_{8} \mathrm{H}_{16} \mathrm{O}_{2}$ cyclic ethers (Figure 13), the prediction by the two models is very different. In the JSR and PFR, the Thion model predicts correctly the peak position around 700 $\mathrm{K}$, but it does not reproduce the earlier peaks $<600 \mathrm{~K}$ (Figure 13a). The Cai model reproduces these earlier peaks, however (Figure 13b). Quantitatively, the Thion model significantly underpredicts the formation of $\mathrm{C}_{8} \mathrm{H}_{16} \mathrm{O}_{2}$ cyclic ethers, but the relative trend between these isomers is well captured by this model, i.e. $\mathrm{C}_{4} \mathrm{OC}_{4} \mathrm{Oa}-\mathrm{d}>\mathrm{C}_{4} \mathrm{OC}_{4} \mathrm{Oa}-2>\mathrm{C}_{4} \mathrm{OC}_{4} \mathrm{Oa}-3$ (Figure 13c). The Cai model predicts a different order, i.e. $\mathrm{C}_{4} \mathrm{OC}_{4} \mathrm{Oa}-2>\mathrm{C}_{4} \mathrm{OC}_{4} \mathrm{Oa}-\mathrm{d}>\mathrm{C}_{4} \mathrm{OC}_{4} \mathrm{Oa}-3$ (Figure $13 \mathrm{~d}$ ), however. This latter model captures the peak mole fraction of $\mathrm{C}_{4} \mathrm{OC}_{4} \mathrm{Oa}-2$ at $\sim 575 \mathrm{~K}$ well, but over-predicts the mole fractions of this species in a higher temperature range and under-predicts the formation of $\mathrm{C}_{4} \mathrm{OC}_{4} \mathrm{Oa}-\mathrm{d}$ and $\mathrm{C}_{4} \mathrm{OC}_{4} \mathrm{Oa}-3$ (Figure 13d). Refinement of the models for the formation of these species may be useful especially in light of their first speciation data reported here. 

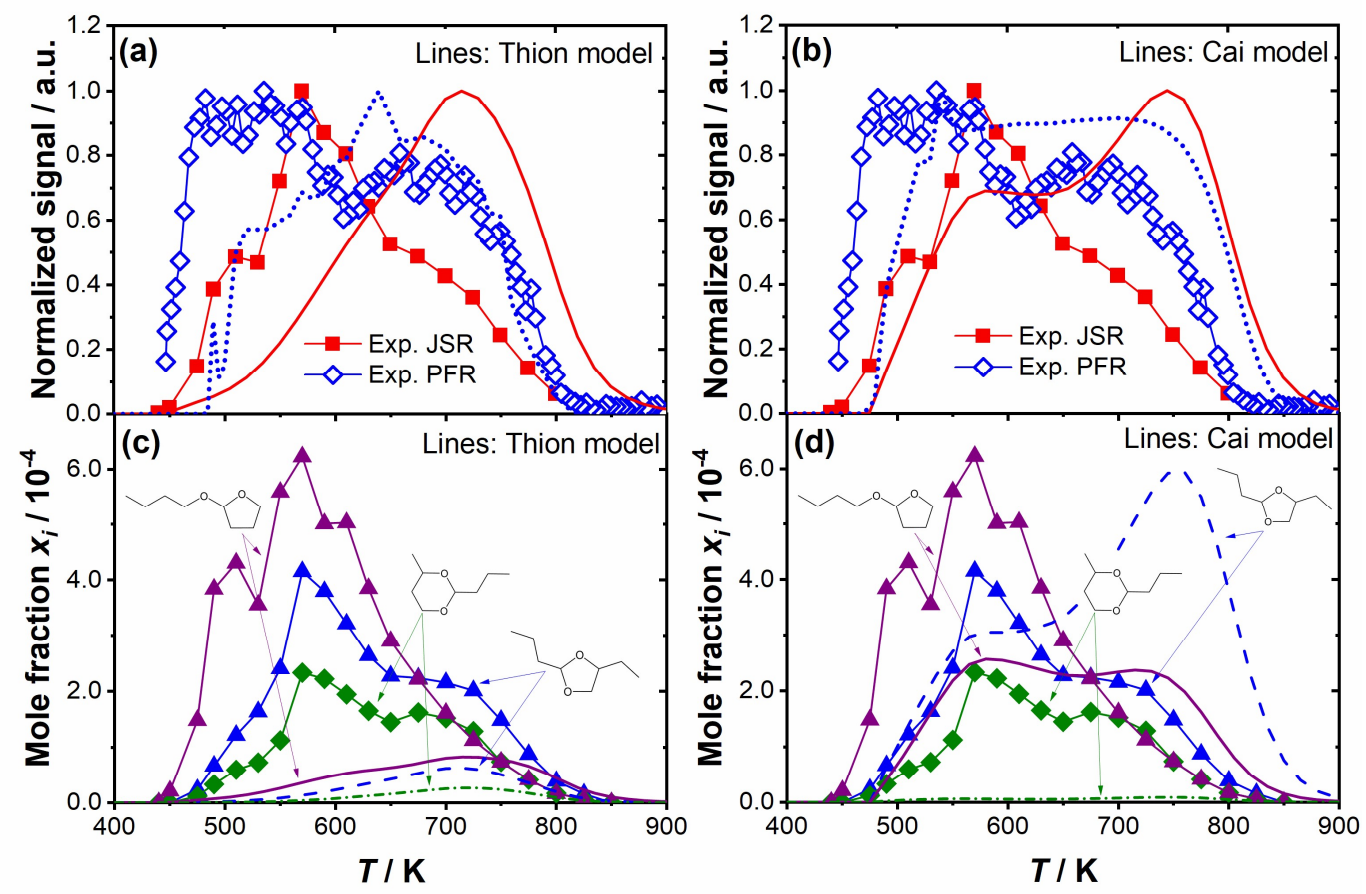

Figure 13. Experimental results and model predictions $[12,15]$ for the sum of $\mathrm{C}_{8} \mathrm{H}_{16} \mathrm{O}_{2}$ cyclic ethers (a,b) and the individual isomers (c,d). Left: Thion model, right: Cai model.

Regarding hydroperoxides, in general the models capture well the peak positions, approximately around 500-600 K as shown in Figure $\mathrm{S} 8\left(\mathrm{CH}_{3} \mathrm{O}_{2} \mathrm{H}\right)$, Figure $\mathrm{S} 11\left(\mathrm{nC}_{3} \mathrm{H}_{7} \mathrm{O}_{2} \mathrm{H}\right)$, and Figure $\mathrm{S} 13\left(\mathrm{C}_{8} \mathrm{H}_{18} \mathrm{O}_{3}\right.$ and $\left.\mathrm{C}_{8} \mathrm{H}_{16} \mathrm{O}_{4}\right)$. However, a large deviation in absolute values is observed between the two models. For example, the prediction of $\mathrm{CH}_{3} \mathrm{O}_{2} \mathrm{H}$ by the Thion model is closer to the experimental data than that by the Cai model. Conversely, the prediction of $\mathrm{nC}_{3} \mathrm{H}_{7} \mathrm{O}_{2} \mathrm{H}_{\text {by }}$ the Cai model is better. The Cai model reproduces $\mathrm{C}_{8} \mathrm{H}_{18} \mathrm{O}_{3}$ in much higher mole fractions than the Thion model, while an opposite trend is noted for $\mathrm{C}_{8} \mathrm{H}_{16} \mathrm{O}_{4}$. Note that $\mathrm{C}_{8} \mathrm{H}_{14} \mathrm{O}_{5}$ and $\mathrm{C}_{8} \mathrm{H}_{16} \mathrm{O}_{6}$ as products of the third $\mathrm{O}_{2}$ addition (Figure 10) were not included in these models.

\subsection{Newly-proposed reaction pathways for DBE LT oxidation}

Based on indications from the present experiments, formation paths of butanoic acid $\left(\mathrm{C}_{3} \mathrm{H}_{7} \mathrm{COOH}\right), n$-butyl butanoate $\left(\mathrm{C}_{4} \mathrm{O}(\mathrm{CO}) \mathrm{C}_{3}\right)$, and butyric anhydride $\left(\mathrm{C}_{8} \mathrm{H}_{14} \mathrm{O}_{3}\right)$, as well as the reaction routes of a third $\mathrm{O}_{2}$ addition are proposed which are summarized in Figure 14. As presented in Figure 14a, $\mathrm{C}_{3} \mathrm{H}_{7} \mathrm{COOH}$ can be formed from KHP (e.g., $\mathrm{C}_{4} \mathrm{OC}_{4} \mathrm{keta}-1$ ) via the Korcek decomposition process (path $\boldsymbol{i}$ ) or via the succession of $\mathrm{O}-\mathrm{OH}$ scission/H-transfer/C-O scission (path ii). Path $\boldsymbol{i}$ is similar to that proposed for $\mathrm{HO}_{2} \mathrm{CH}_{2} \mathrm{CH}_{2} \mathrm{CH}=\mathrm{O}$ in [37], whereas the proposed decomposition of the $\mathrm{OQ}=\mathrm{O}$ radical in path $\boldsymbol{i} i$ is similar to that of the $\mathrm{OCH}_{2} \mathrm{OCHO}$ radical reported 
in [23]. Previous studies [23,35] support the significance of this reaction class (path ii) in the LT consumption of ethers because of its low activation energy, suggesting that it can also be important in the LT oxidation of DBE. Diones (butyric anhydride, $\mathrm{C}_{8} \mathrm{H}_{14} \mathrm{O}_{3}$ ) are expected to be formed from KHP via the formation of the $\mathrm{OQ}=0$ radical by $\mathrm{O}-\mathrm{O}$ scission or via $\mathrm{H}$-abstractions from KHP (path iii, Figure 14a). $n$-Butyl butanoate $\left(\mathrm{C}_{4} \mathrm{O}(\mathrm{CO}) \mathrm{C}_{3}\right)$ can be formed through different routes (Figure 14b) including the recombination/disproportionation of $\mathrm{RO}_{2}$ (e.g., $\mathrm{C}_{4} \mathrm{OC}_{4} \mathrm{H}_{8} \mathrm{OO}$ a) or $\mathrm{H}$-abstractions from $\mathrm{RO}_{2} \mathrm{H}\left(\right.$ e.g., $\left.\mathrm{C}_{8} \mathrm{H}_{18} \mathrm{O}_{3}\right)$.

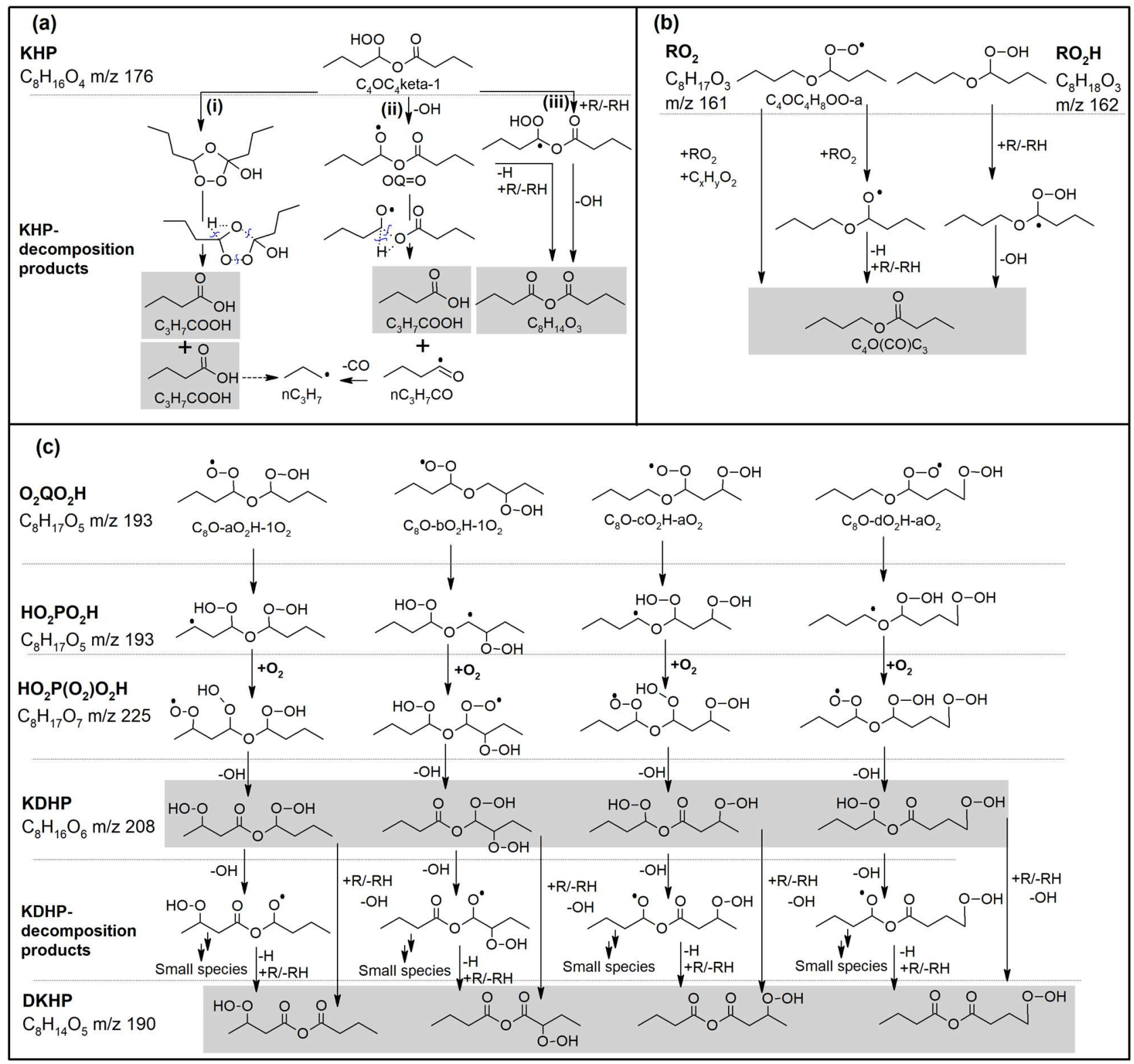

Figure 14. Newly-proposed paths for DBE LT mechanism. (a) Formation of butanoic acid $\left(\mathrm{C}_{3} \mathrm{H}_{7} \mathrm{COOH}\right)$ and butyric anhydride $\left(\mathrm{C}_{8} \mathrm{H}_{14} \mathrm{O}_{3}\right)$. (b) Formation of $n$-butyl butanoate $\left(\mathrm{C}_{4} \mathrm{O}(\mathrm{CO}) \mathrm{C}_{3}\right)$. (c) Third $\mathrm{O}_{2}$ addition. KHP: ketohydroperoxides. KDHP: keto-di-hydroperoxides. DKHP: di-keto-hydroperoxides. 
As presented in Figure 14c, $\mathrm{O}_{2} \mathrm{QO}_{2} \mathrm{H}$ radicals with their long carbon chains have several possibilities to isomerize to $\mathrm{HO}_{2} \mathrm{PO}_{2} \mathrm{H}$ radicals (di-hydroperoxyl-fuel radicals). The presence of the ether oxygen atom reduces also the $\mathrm{C}-\mathrm{H}$ bond energies, and thus favors this isomerization process. These resulting $\mathrm{HO}_{2} \mathrm{PO}_{2} \mathrm{H}$ radicals can react by third $\mathrm{O}_{2}$ addition reactions forming $\mathrm{HO}_{2} \mathrm{P}\left(\mathrm{O}_{2}\right) \mathrm{O}_{2} \mathrm{H}$ radicals, and their subsequent reactions produce di-keto-hydroperoxides (DKHP, $\mathrm{C}_{8} \mathrm{H}_{14} \mathrm{O}_{5}$ ) and keto-di-hydroperoxides (KDHP, $\mathrm{C}_{8} \mathrm{H}_{16} \mathrm{O}_{6}$ ). Species with nominal masses corresponding to these peroxide species were experimentally detected as discussed earlier, supporting the proposed third $\mathrm{O}_{2}$ addition reactions, which is also consistent with recent studies by Wang and coworkers $[39,40]$.

It is suggested that such additional reactions should now be introduced into reaction mechanisms for LT oxidation of DBE, potentially improving the predictive capability of respective kinetic models. In this context it might be mentioned that earlier work on shorterchain ethers, including experiments and simulations for diethyl ether (DEE) $[38,41,42]$, shows some similarities as e.g., a two-NTC behavior, while the reactivity under similar conditions (compare [38]) for both fuels is different. A comprehensive mechanism for the LT oxidation of promising alternative ether fuels might thus be desirable.

\section{Conclusions}

The present paper reports, in unprecedented detail, experimental data for species profiles measured in the low-temperature oxidation of DBE at $0=1$ and near-atmospheric pressure. A suite of three experiments was used with complementary combinations of reactor type and analytic technique, including a JSR coupled with GC-MS, a second JSR with SVUV-PI-MBMS, and a PFR coupled to an EI-MBMS instrument. Temperature-dependent profiles of approximately 40 stable and reactive $\mathrm{C}_{0}-\mathrm{C}_{8}$ intermediates including about 20 newly-detected species were measured, isomers identified, and mole fractions quantified whenever possible. The profound analysis of this dataset focused first on the general fuel consumption behavior, where two NTC zones were observed and could be explained in depth based on the fuel structure and the presently detected intermediate species. The detected species, including particularly acids, cyclic ethers, diones, and possible products of a third $\mathrm{O}_{2}$ addition step, suggest including previously unexplored, plausible reactions in mechanisms describing the LT chemistry of DBE. A comparison of the present data with recent literature DBE models [12,15] shows reasonable agreement for most species that were previously detected, but exhibits significant discrepancies for the newly-detected LT intermediates, suggesting the need for further improvement of the 
kinetic mechanisms. Although the combination of the used analytical techniques showed to be powerful for detection of several species classes, it is clear that these techniques encountered certain limitations for large hydroperoxide species of DBE LT oxidation, and theoretical work as well as the use of other experimental strategies including isotope labeling and highresolution mass spectrometry as used in [39] or potentially photoelectron photoion coincidence (PEPICO) spectroscopy-MBMS as recently reviewed by [43] could be useful to provide further complementary information for fully identifying these species.

\section{Acknowledgements}

Dr. Luc-Sy Tran is grateful to the COST Action CM1404 and the Alexander von HumboldtFoundation for financial support. Partial support from the Deutsche Forschungsgemeinschaft under project K01363/31-1 is gratefully acknowledged. The research at SJTU was supported by the National Natural Science Foundation of China $(51622605,91541201)$ and the Shanghai Science and Technology Committee (No. 17XD1402000). We thank Eike Bräuer for contributing to some of the measurements in Bielefeld, and the participating students for their contribution to the PI-MBMS experiments in Hefei.

\section{List of Supplemental Material}

1/ Experimental data of the present study (excel file)

2/ Supporting information (pdf file)

\section{References}

[1] K. Melin, M. Hurme, Evaluation of lignocellulosic biomass upgrading routes to fuels and chemicals, Cell Chem. Technol. 44 (2010) 117-137.

[2] C. Beatrice, C. Bertoli, J. D’Alessio, N. Del Giacomo, M. Lazzaro, P. Massoli, Experimental characterization of combustion behaviour of new diesel fuels for low emission engines, Combust. Sci. Technol. 120 (1996) 335-355.

[3] N. Miyamoto, H. Ogawa, N.M. Nurun, K. Obata, T. Arima, Smokeless, low NOx, high thermal efficiency, and low noise diesel combustion with oxygenated agents as main fuel, SAE Technical Paper, No. 980506, 1998.

[4] N. Miyamoto, H. Ogawa, M.N. Nabi, Approaches to extremely low emissions and efficient diesel combustion with oxygenated fuels, Int. J. Eng. Res. 1 (2000) 71-85. 
[5] B. Heuser, P. Mauermann, R. Wankhade, F. Kremer, S. Pischinger, Combustion and emission behavior of linear C8-oxygenates, Int. J. Eng. Res. 16 (2015) 627-638.

[6] J. Beeckmann, M.M. Aye, R. Gehmlich, N. Peters, Experimental Investigation of the Spray Characteristics of Di-n-Butyl Ether (DNBE) as an Oxygenated Compound in Diesel Fuel, SAE Technical Paper, No. 2010-01-1502, 2010.

[7] L. Guan, C. Tang, K. Yang, J. Mo, Z. Huang, Effect of di-n-butyl ether blending with soybeanbiodiesel on spray and atomization characteristics in a common-rail fuel injection system, Fuel 140 (2015) 116-125.

[8] B. Heuser, F. Kremer, S. Pischinger, J. Klankermayer, Optimization of Diesel Combustion and Emissions with Tailor-Made Fuels from Biomass, SAE Int. J. Fuels Lubr. 6 (2013) 922934.

[9] C. Tang, L. Guan, Z. Feng, C. Zhan, K. Yang, Z. Huang, Effect of di-n-butyl ether blending with soybean-biodiesel on the near-nozzle spray characteristics, Fuel 191 (2017) 300-311.

[10] A. García, J. Monsalve-Serrano, D. Villalta, M. Zubel, S. Pischinger, Potential of 1-octanol and di-n-butyl ether (DNBE) to improve the performance and reduce the emissions of a direct injected compression ignition diesel engine, Energ. Convers. Manage. 177 (2018) 563571.

[11] L. Guan, C. Tang, K. Yang, J. Mo, Z. Huang, Experimental and kinetic study on ignition delay times of di-n-butyl ether at high temperatures, Energy Fuels 28 (2014) 5489-5496.

[12] L. Cai, A. Sudholt, D.J. Lee, F.N. Egolfopoulos, H. Pitsch, C.K. Westbrook, S.M. Sarathy, Chemical kinetic study of a novel lignocellulosic biofuel: Di-n-butyl ether oxidation in a laminar flow reactor and flames, Combustion and Flame. 161 (2014) 798-809.

[13] J. Wullenkord, L.-S. Tran, J. Böttchers, I. Graf, K. Kohse-Höinghaus, A laminar flame study on di-n-butyl ether as a potential biofuel candidate, Combust. Flame 190 (2018) 36-49.

[14] Z. Gao, L. Zhu, X. Zou, C. Liu, B. Tian, Z. Huang, Soot reduction effects of dibutyl ether (DBE) addition to a biodiesel surrogate in laminar coflow diffusion flames, Proc. Combust. Inst. 37 (2019), 1265-1272.

[15] S. Thion, C. Togbé, Z. Serinyel, G. Dayma, P. Dagaut, A chemical kinetic study of the oxidation of dibutyl-ether in a jet-stirred reactor, Combust. Flame 185 (2017) 4-15.

[16] J. Bugler, A. Rodriguez, O. Herbinet, F. Battin-Leclerc, C. Togbe, G. Dayma, P. Dagaut, H.J. Curran, An experimental and modelling study of n-pentane oxidation in two jet-stirred reactors: The importance of pressure-dependent kinetics and new reaction pathways, Proc. Combust. Inst. 36 (2017) 441-448.

[17] 0. Herbinet, F. Battin-Leclerc, Progress in understanding low-temperature organic compound oxidation using a jet-stirred reactor, Int. J. Chem. Kinet. 46 (2014) 619-639. 
[18] Z. Zhou, X. Du, J. Yang, Y. Wang, C. Li, S. Wei, L. Du, Y. Li, F. Qi, Q. Wang, The vacuum ultraviolet beamline/endstations at NSRL dedicated to combustion research, J. Synchrotron Radiat. 23 (2016) 1035-1045.

[19] X. Zhang, L. Ye, Y. Li, Y. Zhang, C. Cao, J. Yang, Z. Zhou, Z. Huang, F. Qi, Acetaldehyde oxidation at low and intermediate temperatures: An experimental and kinetic modeling investigation, Combust. Flame 191 (2018) 431-441.

[20] O. Herbinet, F. Battin-Leclerc, S. Bax, H. Le Gall, P.-A. Glaude, R. Fournet, Z. Zhou, L. Deng, H. Guo, M. Xie, F. Qi, Detailed product analysis during the low temperature oxidation of nbutane, Phys. Chem. Chem. Phys. 13 (2011) 296-308.

[21] C. Hemken, U. Burke, K.-Y. Lam, D.F. Davidson, R.K. Hanson, K.A. Heufer, K. Kohse-Höinghaus, Toward a better understanding of 2-butanone oxidation: Detailed species measurements and kinetic modeling, Combust. Flame 184 (2017) 195-207.

[22] L.-S. Tran, Z. Wang, H.-H. Carstensen, C. Hemken, F. Battin-Leclerc, K. Kohse-Höinghaus, Comparative experimental and modeling study of the low- to moderate-temperature oxidation chemistry of 2,5-dimethylfuran, 2-methylfuran, and furan, Combust. Flame 181 (2017) 251-269.

[23] Z. Wang, X. Zhang, L. Xing, L. Zhang, F. Herrmann, K. Moshammer, F. Qi, K. Kohse-Höinghaus, Experimental and kinetic modeling study of the low- and intermediatetemperature oxidation of dimethyl ether, Combust. Flame 162 (2015) 1113-1125.

[24] M. Schenk, L. Leon, K. Moshammer, P. Oßwald, T. Zeuch, L. Seidel, F. Mauss, K. KohseHöinghaus, Detailed mass spectrometric and modeling study of isomeric butene flames, Combust. Flame 160 (2013) 487-503.

[25] A. Cuoci, A. Frassoldati, T. Faravelli, E. Ranzi, OpenSMOKE++: An object-oriented framework for the numerical modeling of reactive systems with detailed kinetic mechanisms, Comput. Phys. Commun. 192 (2015) 237-264.

[26] H. Jin, J. Pieper, C. Hemken, E. Bräuer, L. Ruwe, K. Kohse-Höinghaus, Chemical interaction of dual-fuel mixtures in low-temperature oxidation, comparing n-pentane/dimethyl ether and n-pentane/ethanol, Combust. Flame 193 (2018) 36-53.

[27] S.M. Sarathy, S. Vranckx, K. Yasunaga, M. Mehl, P. Oßwald, W.K. Metcalfe, C.K. Westbrook, W.J. Pitz, K. Kohse-Höinghaus, R.X. Fernandes, H.J. Curran, A comprehensive chemical kinetic combustion model for the four butanol isomers, Combust. Flame 159 (2012) 20282055.

[28] E.R. Ritter and J.W. Bozzelli, THERM: Thermodynamic property estimation for gas phase radicals and molecules, International Journal of Chemical Kinetics. 23 (1991) 767-778. 
[29] Y. Fenard, P. Dagaut, G. Dayma, F. Halter, F. Foucher, Experimental and kinetic modeling study of trans-2-butene oxidation in a jet-stirred reactor and a combustion bomb, Proc. Combust. Inst. 35 (2015) 317-324.

[30] J. Mendes, C.-W. Zhou, H.J. Curran, Rate constant calculations of H-atom abstraction reactions from ethers by $\mathrm{HO}_{2}$ radicals, J. Phys. Chem. A. 118 (2014) 1300-1308.

[31] M. Cord, B. Husson, J.C. Lizardo Huerta, O. Herbinet, P.-A. Glaude, R. Fournet, B. Sirjean, F. Battin-Leclerc, M. Ruiz-Lopez, Z. Wang, M. Xie, Z. Cheng, F. Qi, Study of the low temperature oxidation of propane, J. Phys. Chem. A. 116 (2012) 12214-12228.

[32] NIST Chemistry WebBook, available at < http://webbook.nist.gov/chemistry/>.

[33] J.A. Montgomery, M.J. Frisch, J.W. Ochterski, G.A. Petersson, A complete basis set model chemistry. VI. Use of density functional geometries and frequencies, J. Chem. Phys. 110 (1999) 2822-2827.

[34] M.J. Frisch, G.W. Trucks, H.B. Schlegel, G.E. Scuseria, M.A. Robb, et al., Gaussian 09, Revision B.01, Gaussian, Inc., Wallingford, CT, 2009.

[35] K. Moshammer, A.W. Jasper, D.M. Popolan-Vaida, A. Lucassen, P. Diévart, H. Selim, A.J. Eskola, C.A. Taatjes, S.R. Leone, S.M. Sarathy, Y. Ju, P. Dagaut, K. Kohse-Höinghaus, N. Hansen, Detection and identification of the keto-hydroperoxide (HOOCH2OCHO) and other intermediates during low-temperature oxidation of dimethyl ether, J. Phys. Chem. A 119 (2015) 7361-7374]

[36] Z. Wang, O. Herbinet, N. Hansen, F. Battin-Leclerc, Exploring hydroperoxides in combustion: History, recent advances and perspectives, Prog. Energy Combust. Sci. 73 (2019) 132-181.

[37] A. Jalan, I.M. Alecu, R. Meana-Paneda, J. Aguilera-Iparraguirre, K.R. Yang, S.S. Merchant, D.G. Truhlar, W.H. Green, New Pathways for Formation of Acids and Carbonyl Products in LowTemperature Oxidation: The Korcek Decomposition of $\gamma$-Ketohydroperoxides, J. Am. Chem. Soc. 135 (2013) 11100-11114.

[38] L.-S. Tran, O. Herbinet, Y. Li, J. Wullenkord, M. Zeng, E. Bräuer, F. Qi, K. Kohse-Höinghaus, F. Battin-Leclerc, Low-temperature gas-phase oxidation of diethyl ether: Fuel reactivity and fuel-specific products, Proc. Combust. Inst. 37 (2019) 511-519.

[39] Z. Wang, D.M. Popolan-Vaida, B. Chen, K. Moshammer, S.Y. Mohamed, H. Wang, S. Sioud, M.A. Raji, K. Kohse-Höinghaus, N. Hansen, P. Dagaut, S.R. Leone, S.M. Sarathy, Unraveling the structure and chemical mechanisms of highly oxygenated intermediates in oxidation of organic compounds, Proc. Nat. Acad. Sci. USA 114 (2017)13102-13107. 
[40] Z. Wang, S.Y. Mohamed, L. Zhang, K. Moshammer, D.M. Popolan-Vaida, V.S.B. Shankar, A. Lucassen, L. Ruwe, N. Hansen, P. Dagaut, S.M. Sarathy, New insights into the lowtemperature oxidation of 2-methylhexane, Proc. Combust. Inst. 36 (2017) 373-382.

[41] L.-S. Tran, J. Pieper, H.-H. Carstensen, H. Zhao, I. Graf, Y. Ju, F. Qi, K. Kohse-Höinghaus, Experimental and kinetic modeling study of diethyl ether flames, Proc. Combust. Inst. 36 (2017) 1165-1173.

[42] K. Yasunaga, F. Gillespie, J.M. Simmie, H.J. Curran, Y. Kuraguchi, H. Hoshikawa, M. Yamane, Y. Hidaka, A multiple shock tube and chemical kinetic modeling study of diethyl ether pyrolysis and oxidation, J. Phys. Chem. A 114 (2010) 9098-9109.

[43] T. Baer, R.P. Tuckett, Advances in threshold photoelectron spectroscopy (TPES) and threshold photoelectron photoion coincidence (TPEPICO). Phys. Chem. Chem. Phys. 19 (2017) 9698-9723 